U.S. Department of the Interior

U.S. Geological Survey

\title{
Water-Quality Conditions During Low Flow in the Lower Youghiogheny River Basin, Pennsylvania, October 5-7, 1998
}

Water-Resources Investigations Report 01-4189

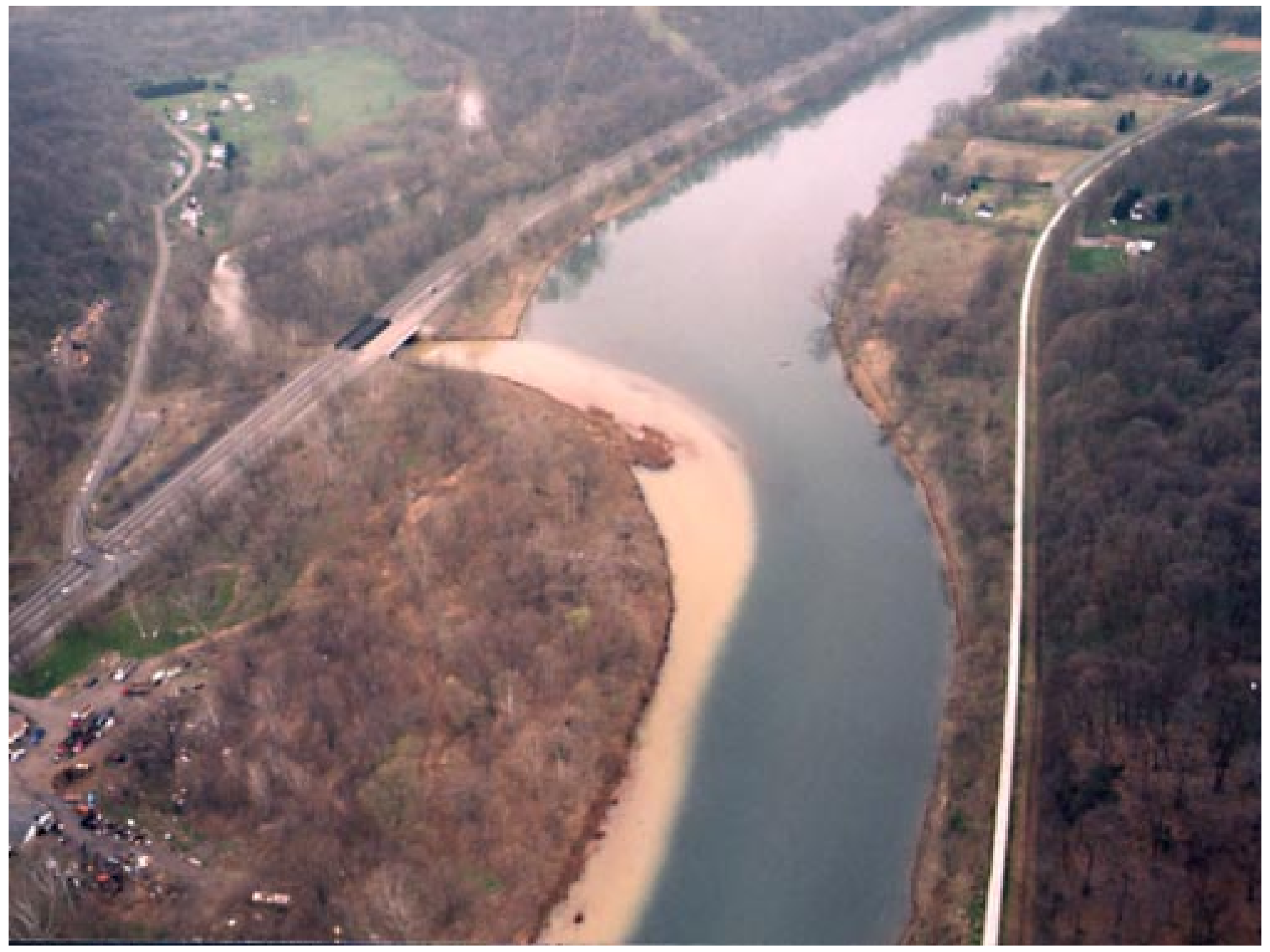

In cooperation with

U.S. DEPARTMENT OF ENERGY,

NATIONAL ENERGY TECHNOLOGY LABORATORY

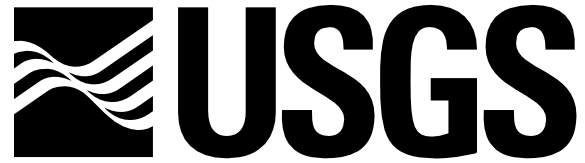

science for a changing world

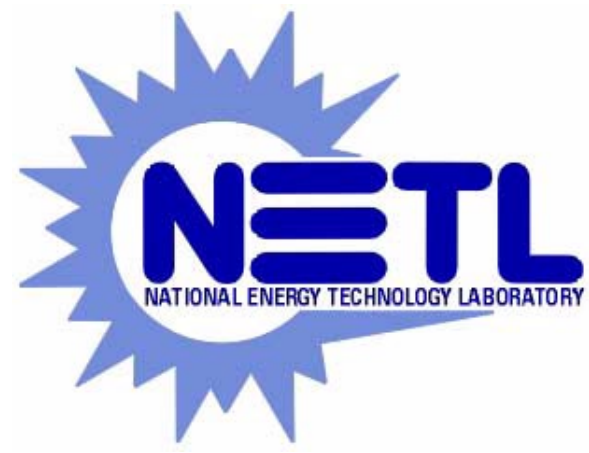


Front cover photograph:

Youghiogheny River near West Newton, Pa., showing confluence with Sewickley Creek. Photograph by Terry E. Ackman, U.S. Department of Energy. 


\section{Water-Quality Conditions During Low Flow in the Lower Youghiogheny River Basin, Pennsylvania, October 5-7, 1998}

by James I. Sams, III, U.S. Geological Survey; Karl T. Schroeder, U.S. Department of Energy; Terry E. Ackman, U.S. Department of Energy; J. Kent Crawford, U.S. Geological Survey; and Kim L. Otto, U.S. Geological Survey

Water-Resources Investigations Report 01-4189 


\section{U.S. DEPARTMENT OF THE INTERIOR \\ GALE A. NORTON, Secretary}

\section{U.S. GEOLOGICAL SURVEY}

Charles G. Groat, Director

For additional information write to:

District Chief

U.S. Geological Survey

215 Limekiln Road

New Cumberland, Pennsylvania 17070-2424
Copies of this report may be purchased from:

U.S. Geological Survey

Branch of Information Services

Box 25286

Denver, Colorado 80225-0286 


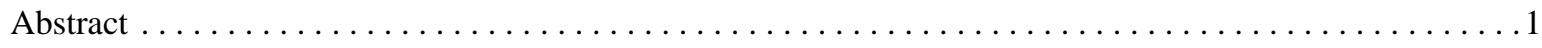

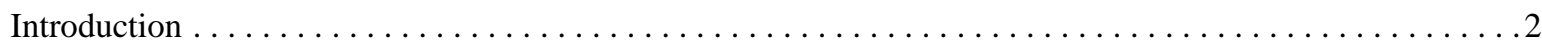

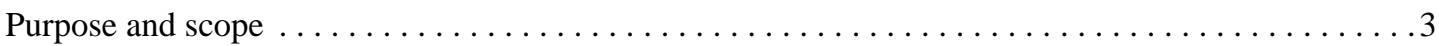

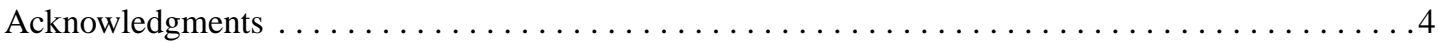

Environmental setting of the Youghiogheny River Basin $\ldots \ldots \ldots \ldots \ldots \ldots \ldots \ldots \ldots \ldots \ldots \ldots \ldots \ldots \ldots \ldots$

Effects of historical coal mining in the Lower Youghiogheny River Basin. . . . . . . . . . . . . . .

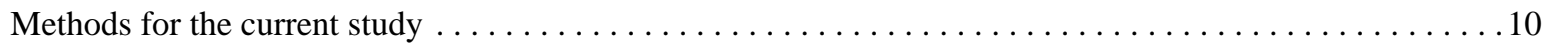

Hydrologic and water-quality conditions measured during low flow $\ldots \ldots \ldots \ldots \ldots$

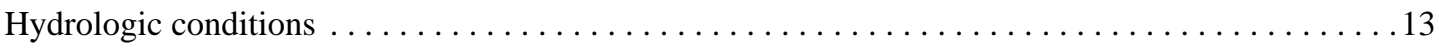

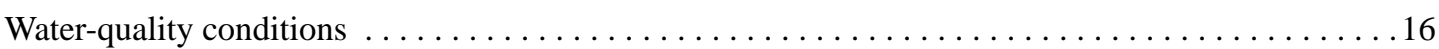

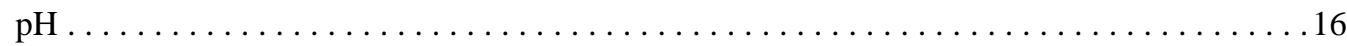

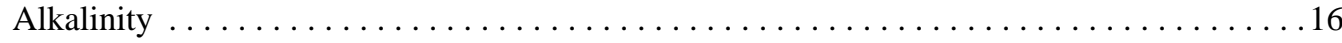

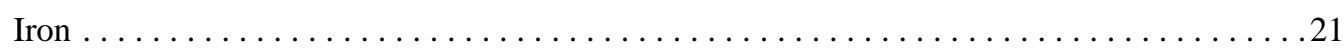

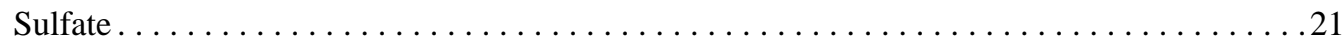

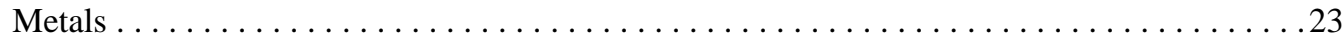

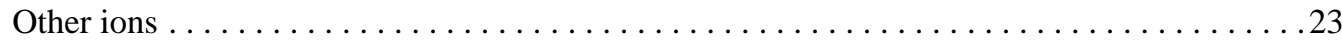

Companion research at National Energy Technology Laboratory . . . . . . . . . . . . . . . . . . 30

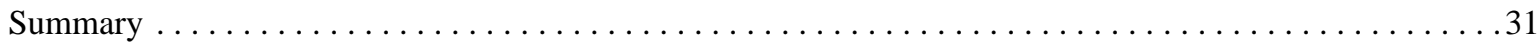

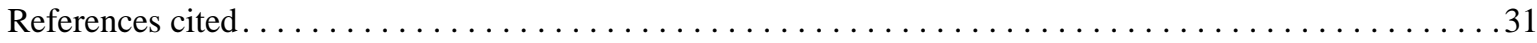

\section{ILLUSTRATIONS}

Figures 1. Map showing the Youghiogheny River Basin and location of the study area

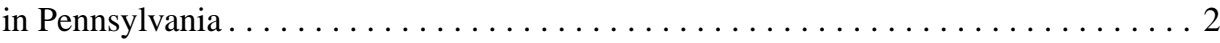

2. Graph showing historical coal production in the three Pennsylvania counties that compose the Lower Youghiogheny River Basin, 1925-95 . . . . . . . . . . . . . 3

3-4. Maps showing:

3. Rock strata in the Youghiogheny River Basin, Pennsylvania, Maryland, and West Virginia $\ldots \ldots \ldots \ldots \ldots \ldots \ldots \ldots \ldots \ldots \ldots \ldots \ldots \ldots \ldots \ldots \ldots \ldots \ldots \ldots \ldots \ldots \ldots$

4. Historical sulfate loads from 104 mine discharges in the Lower Youghiogheny

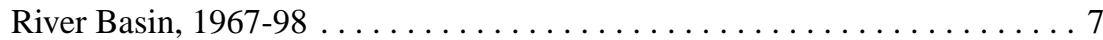

5. Graph showing distribution of historical sulfate loads for mine discharges by subbasins

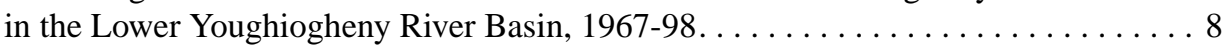

6. Map showing locations of main-stem, tributary, and mine-discharge sampling sites in the Lower Youghiogheny River Basin, October 5-7, 1998. . . . . . . . . . . 11 


\section{ILLUSTRATIONS-Continued}

7-9. Graphs showing:

7. Streamflows and unaccounted for gains and losses in main-stem sites during the synoptic survey in the Lower Youghiogheny River Basin,

October 5-7, $1998 \ldots \ldots \ldots \ldots \ldots \ldots$. . . . . . . . . . . . . . . . . . . 14

8. Flow-duration curves for the Youghiogheny River at Connellsville and

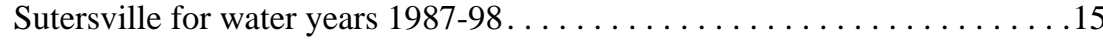

9. Measured alkalinity loads and concentrations at main-stem sites during the synoptic survey in the Lower Youghiogheny River Basin, October 5-7, 1998

10. Pie chart showing sources of alkalinity load (43 tons per day) between the Lower Youghiogheny River upstream from Indian Creek (site YR_A) and McKeesport (site YR_K) during the synoptic survey in the Lower Youghiogheny River Basin,

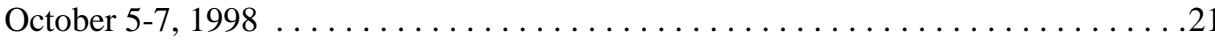

11. Graph showing measured sulfate loads and concentrations at main-stem sites during the synoptic survey in the Lower Youghiogheny River Basin, October 5-7, 1998 . . . 22

12. Pie chart showing sources of sulfate load (110 tons per day) between the Lower Youghiogheny River upstream from Indian Creek (site YR_A) and McKeesport (site YR_K) during the synoptic survey in the Lower Youghiogheny River Basin,

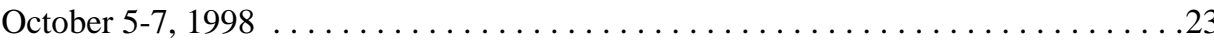

13. Graph showing total ion loads that were not accounted for in measurements of tributary inflows, Lower Youghiogheny River Basin, October 5-7, 1998 . . . . . . . . . . . 30

\section{TABLES}

Table 1. Summary of historical coal-mining activities from 1890 to 1998 by drainage basin within

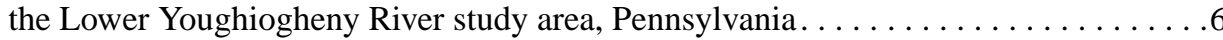

2. Ten largest of 104 sulfate-load sites from historical mine-drainage database (1967-98) for the Lower Youghiogheny River Basin $\ldots \ldots \ldots \ldots \ldots \ldots \ldots$

3. Main-stem, tributary, and mine-discharge sampling sites for the Lower Youghiogheny River Basin synoptic survey, October 5-7, $1998 \ldots \ldots \ldots \ldots \ldots \ldots \ldots \ldots \ldots \ldots$

4. Constituents analyzed for in the laboratory and the method reporting limits used for this study in the Lower Youghiogheny River Basin . . . . . . . . . . . . . . 13

5. Field measurements of physical properties and constituents and results of chemical analyses for major ions for water samples collected from main-stem, tributary, and mine-discharge sites in the Lower Youghiogheny River Basin, October 5-7, 1998 . . 17

6. Results of chemical analyses for metals for water samples collected from main-stem, tributary, and mine-discharge sites in the Lower Youghiogheny River Basin,

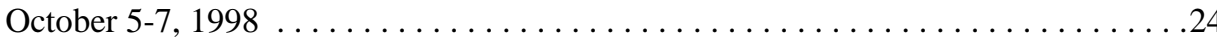




\section{CONVERSION FACTORS, VERTICAL DATUM, \\ AND ABBREVIATED WATER-QUALITY UNITS}

Multiply

foot (ft)

mile (mi)

square mile $\left(\mathrm{mi}^{2}\right)$

cubic foot per second $\left(\mathrm{ft}^{3} / \mathrm{s}\right)$

cubic foot per second per square mile $\left[\left(\mathrm{ft}^{3} / \mathrm{s}\right) / \mathrm{mi}^{2}\right]$

pound (lb)

ton, short $(2,000 \mathrm{lb})$
By

To obtain

Length

0.3048

1.609

Area

2.590

Flow rate

0.02832

0.01093

\section{Mass}

0.4536

0.9072 meter

kilometer

square kilometer

cubic meter per second cubic meter per second per square kilometer

kilogram

megagram

Abbreviated water-quality units used in report:

$\mathrm{lb} / \mathrm{d}$, pounds per day

$\mathrm{mg} / \mathrm{L}$, milligrams per liter

$\mu \mathrm{g} / \mathrm{L}$, micrograms per liter

$\mu \mathrm{S} / \mathrm{cm}$, microsiemens per centimeter at 25 degrees Celsius

ton/d, tons per day

Sea level: In this report, "sea level" refers to the National Geodetic Vertical Datum of 1929-a geodetic datum derived from a general adjustment of the first-order level nets of the United States and Canada, formerly called Sea Level Datum of 1929. 


\title{
Water-Quality Conditions During Low Flow in the Lower Youghiogheny River Basin, Pennsylvania, October 5-7, 1998
}

\author{
by James I. Sams, III, Karl T. Schroeder, Terry E. Ackman, \\ J. Kent Crawford, and Kim L. Otto
}

\begin{abstract}
In October 1998, a chemical synoptic survey was conducted by the U.S. Geological Survey, in cooperation with the U.S. Department of Energy, National Energy Technology Laboratory, in the Lower Youghiogheny River Basin in Pennsylvania to give a snapshot of present (1998) water quality during low-flow conditions. Water samples from 38 sites-12 mainstem sites, 22 tributaries, and 4 mine discharges that discharge directly to the Youghiogheny River-were used to identify sources of contaminants from mining operations. Specific conductance, water temperature, $\mathrm{pH}$, and dissolved oxygen were measured in the field at each site and concentrations of major ions and trace elements were measured in the laboratory.

Unaccounted for gains and losses in streamflow were measured during the study. Unaccounted for losses in streamflow might be attributed to water loss through streambed fractures. Extensive mine tunnels are present in the basin and loss of water to these tunnels seems likely. Unaccounted for gains in streamflow may be from unmeasured tributaries or surface seeps, but most of the gains are suspected to come from artesian flow through fractures in the streambed from underground mine pools. Influent flows of rust-colored water were noted in some river sections.

The $\mathrm{pH}$ values for all the samples collected during this survey were above 5.8, and most (33 of 38 samples) were above 7.0. Samples from the four minedischarge sites also had $\mathrm{pH}$ values between 6.3 and 6.7. The lowest $\mathrm{pH}(5.8)$ was in a tributary, Galley Run. All 38 sampling sites had net alkalinity.

The alkalinity load in the Youghiogheny River increased between Connellsville and McKeesport from 35 to 79 tons per day. Above Smithton, the measured alkalinity load in the Lower Youghiogheny River agreed well with the estimated alkalinity load. Below Smithton, measured alkalinity loads in the Lower Youghiogheny River are greater than calculated loads,
\end{abstract}

resulting in unaccounted for gains in alkalinity. These gains are believed to be from seeps in the streambed. Approximately one-third of the load of total alkalinity in the Youghiogheny River at McKeesport is attributed to Sewickley Creek, which contri-butes 14 tons per day.

Sulfate concentrations in the Youghiogheny River steadily increase from 33 milligrams per liter at Connellsville to 77 milligrams per liter near McKeesport. The measured concentrations of sulfate exceeded Pennsylvania water-quality standards at four tributary sites (Galley Run, Hickman Run, Sewickley Creek, and Gillespie Run) and all four mine-discharge sites but not at any main-stem sites. A large increase in sulfate load between West Newton and Sutersville can be attributed almost entirely to the contribution from Sewickley Creek (49 tons per day). Approximately 25 percent of the load measured between Connellsville and McKeesport is unaccounted for. These gains are believed to be from seeps in the streambed from underground mine pools.

Similar patterns also were observed for loads of sodium, calcium, and magnesium. Unmeasured inputs from mine drainage are believed to be the source of these loads. Elevated concentrations (above background levels) of chemicals associated with drainage from coal-mining operations were measured in samples from tributaries, especially from Galley Run, Gillespie Run, and Sewickley Creek, and from the mine-discharge sites.

The synoptic survey conducted for this study was successful in identifying generalized reaches of the Youghiogheny River where unaccounted for loads of constituents associated with mining activities are entering the river. However, the survey was not able to pinpoint the location of these loads. Remote-sensing techniques, such as thermal infrared imaging by the National Energy Technology Laboratory, could be useful for determining the precise locations of these inputs. 


\section{INTRODUCTION}

More than any other industry, coal production has been central to the economy and lifestyle of many communities in the Youghiogheny River Basin in Pennsylvania. The Youghiogheny River Basin (fig. 1) was recognized for its coal resources as early as 1770 when George Washington wrote, "The coal seemed to be of the very best kind..." (Palmer, 1984). From small operations in the early 1800's, coal production expanded greatly after the industrial revolution of the late 19th century. Both surface- and deep-mining techniques were used in the Youghiogheny River Basin during the 1830's with the development of coked coal as fuel for hot-air blast furnaces (Palmer, 1984). During the late 1800's, coking became one of the premier

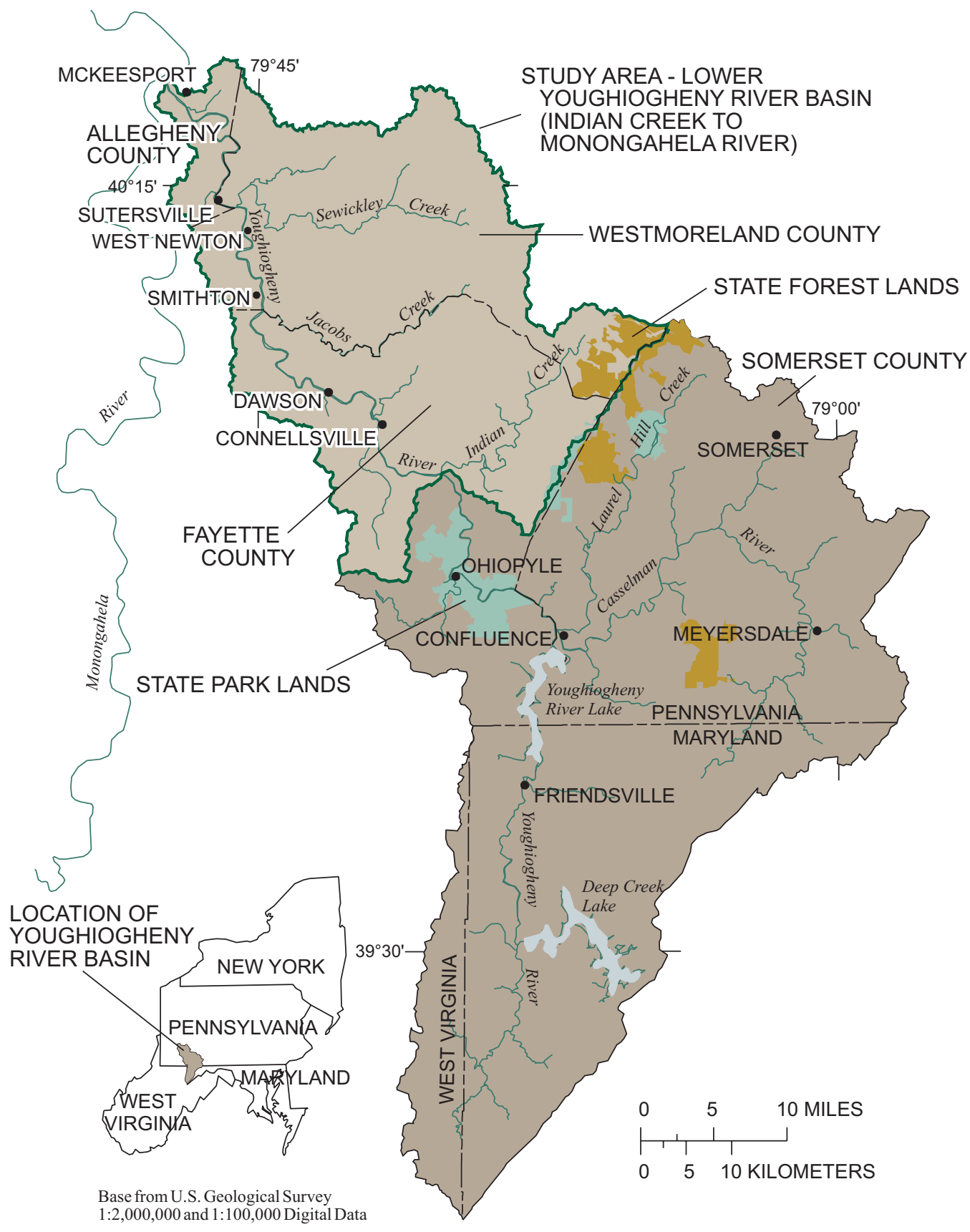

Figure 1. The Youghiogheny River Basin and location of the study area in Pennsylvania. 
industries in the Youghiogheny River Basin. The largest coking centers developed along the Youghiogheny River at cities like Connellsville and Star Junction (Mackin Engineering, 1997). During the period between 1860 and 1919, western Pennsylvania became the world leader in bituminous coal mining and steel production. Coal production peaked in Pennsylvania in 1918 at 177 million tons during World War I. According to county coal-production data (Pennsylvania Coal Association, 1995), coal production in the Lower Youghiogheny River Basin has been decreasing steadily since the early 1940's (fig. 2).

Today, the region is no longer a booming coal and steel-making center. More and more, the river is being used for recreation. For example, the 43-mi Youghiogheny River Trail, a multi-use recreational trail built on the banks of the river between McKeesport and Connellsville, attracts 200,000 to 300,000 people annually (Mackin Engineering, 1997). Yet in many areas of the basin, mine drainage from active and abandoned coal mines contributes elevated concentrations (above background levels) of acidity, sulfate, and metals to the Youghiogheny River. The U.S. Office of Surface Mining indicates 280 abandoned-mine sites currently (1998) are present within the Youghiogheny River Basin. These sites contain environmental hazards such as dangerous mine highwalls, contaminated water from mine drainage, open portals, land subsidence, clogged streams, and dangerous impoundments (U.S. Office of Surface Mining, 1998). Mine drainage within the Youghiogheny River Basin has resulted in an estimated 86 stream miles with a "NO FISH" designation according to a 1995 U.S. Environmental Protection Agency (USEPA) study of mine-drainage effects to water quality (U.S. Environmental Protection Agency, 1995).

Planning is proceeding to restore the river to its former natural state to support the new recreationally based economy. Local conservation groups and watershed associations are developing plans that define problem areas and set forth remediation actions necessary to correct environmental problems. One major challenge is to correct the mine drainage that has effected the water quality in the Youghiogheny River. A renewed Youghiogheny River commonly is cited as a key element in the economic revitalization of this region. A cleaner, healthier river will provide recreational opportunities and an improved quality of life in the region. Improved water quality is central to this vision of progress.

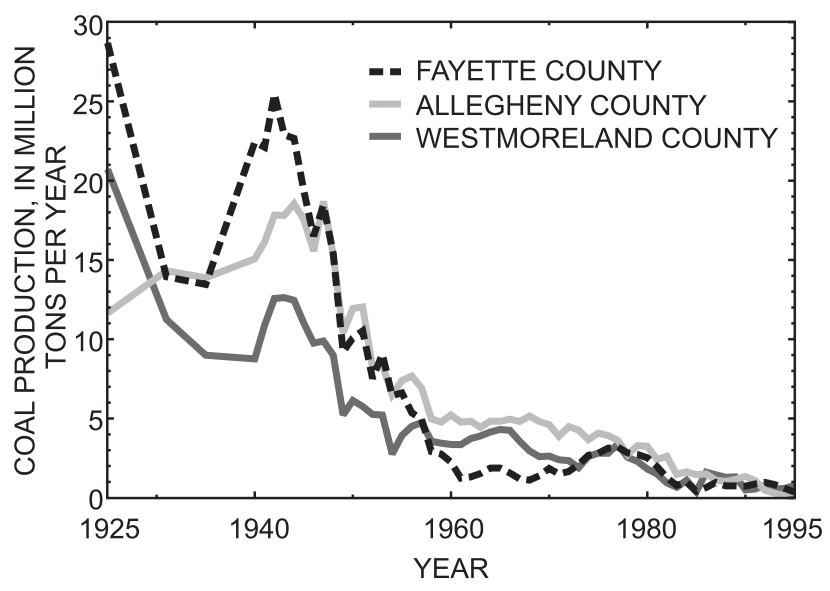

Figure 2. Historical coal production in the three Pennsylvania counties that compose the Lower Youghiogheny River Basin, 1925-95 (Pennsylvania Coal Association, 1995).

A cooperative project between the U.S. Geological Survey (USGS) and the U.S. Department of Energy (DOE), National Energy Technology Laboratory (NETL), was started in 1998 to assess the water quality of the Lower Youghiogheny River Basin. The assessment included a chemical synoptic survey in the Lower Youghiogheny River Basin during low flow to give a snapshot of present (1998) water-quality conditions. Data from the synoptic survey are being used to support remote-sensing technologies utilized by the DOE NETL to identify mine discharges and prioritize treatment options. A plan for improving the stream's water quality then can be formulated.

\section{Purpose and Scope}

This report reviews historical water-quality data and evaluates present-day water-quality conditions during low flow in the Lower Youghiogheny River Basin during October 5-7, 1998. Water samples from 38 sites-12 main-stem sites, 22 tributaries, and 4 known mine discharges that discharge directly to the Youghiogheny River-were used to identify sources of contaminants from mining operations. Specific conductance, water temperature, $\mathrm{pH}$, and dissolved-oxygen concentration were measured at each site. Sample collection during a low-flow period is important because small but potentially appreciable mine drainages are not diluted by increased volumes of rain water. Historical data on mine drainages from 1967 to 1998 were compiled from several databases in order to identify those mine drainages in the Lower Youghiogheny River Basin that are major sources of acidity, metals, and sulfate. 


\section{Acknowledgments}

Assistance from the following organizations is gratefully acknowledged:

- Pennsylvania Department of Environmental Protection

- Youghiogheny River Council

- Regional Trails Corporation

- Penn's Corner Resource Conservation and Development Area, U.S. Department of Agriculture

- AmeriCorps

- Western Pennsylvania Coalition for Abandoned Mine Reclamation

\section{ENVIRONMENTAL SETTING OF THE YOUGHIOGHENY RIVER BASIN}

The Youghiogheny River receives drainage from $1,763 \mathrm{mi}^{2}$ in western Maryland, northeastern West Virginia, and southwestern Pennsylvania and is a tributary to the Monongahela River near McKeesport, $\mathrm{Pa}$.

(fig. 1). The basin lies within the Appalachian Plateau Physiographic Province and contains sedimentary rocks of Mississippian and Pennsylvanian age. Approximately 60 percent of the basin is underlain by bituminous coal, a major natural resource for the economy of the basin (fig. 3). Coal has been mined in the basin since the early 1800's from the Pittsburgh, Redstone, Sewickley, Freeport, Kittanning, Bakerstown, and Brushcreek coal beds. The most significant coal bed in the basin is the Pittsburgh coal seam, which has been referred to as the most valuable minable deposit in the world for its use in the iron and steel industry (Edmunds and Koppe, 1968).

The 1992 LANDSAT satellite imagery (U.S. Geological Survey, 1998) shows land cover in the Youghiogheny River Basin is 68 percent forest, 27 percent agriculture, and 3 percent urban or commercial. The remaining 2 percent of the land area is classified as open water, wetlands, and surface mines or quarries (U.S. Geological Survey, 1998). The 1992 LANDSAT imagery, however, does not accurately represent the extent of mining because many older surface mines are now revegetated and underground mining, as the name implies, takes place below the surface.
The Youghiogheny River cuts through the ridges of the Appalachian Mountains, which trend in a southwest to northeast direction. The maximum elevation in the basin is 3,300 ft above sea level at the southernmost end of the basin drainage divide. The lowest elevation is $720 \mathrm{ft}$ at the mouth of the Youghiogheny River near McKeesport, Pa.

About 336,000 people live in the Youghiogheny River Basin; the highest population density is in the lower part of the basin downstream from Connellsville (Palmer, 1984).

\section{EFFECTS OF HISTORICAL COAL MINING IN THE LOWER YOUGHIOGHENY RIVER BASIN}

Coal, which brought prosperity to many small towns during the peak coal-production years of the early 1900's, appreciably affected the land and water resources of the Lower Youghiogheny River Basin. "... mine drainage from abandoned sites remains the single biggest source of surface water-use impairment in the Commonwealth." This quote, from Pennsylvania's 1998 Water Quality Assessment (Pennsylvania Department of Environmental Protection, 1998), points to the main cause of water-quality impairment in Pennsylvania, but the statement also is true for the Lower Youghiogheny River Basin. Approximately 147 Abandoned Mine Land (AML) sites were present in 1998 within the Lower Youghiogheny River study area (U.S. Office of Surface Mining, 1998) (table 1). Most of the AML sites are in the Sewickley Creek Basin (67), Jacobs Creek Basin (31), Indian Creek Basin (17), and in the flood plain of the Youghiogheny River (17). Of these AML sites, many still have a mine-drainage problem. A total of 482 mine sites historically have operated within the Lower Youghiogheny River study area (Data on file at the offices of the U.S. Office of Surface Mining, U.S. Geological Survey, and the U.S. Environmental Protection Agency) (table 1). Most mine operations were initiated prior to 1980 , and most were underground mines. Many of the environmental laws that regulate coal mining were enacted through the passage of the Surface Mining Control and Reclamation Act of 1977 (SMCRA) (Public Law 95-87). Consequently, much of the mining in the Lower Youghiogheny Basin was not subject to present environmental regulations. 


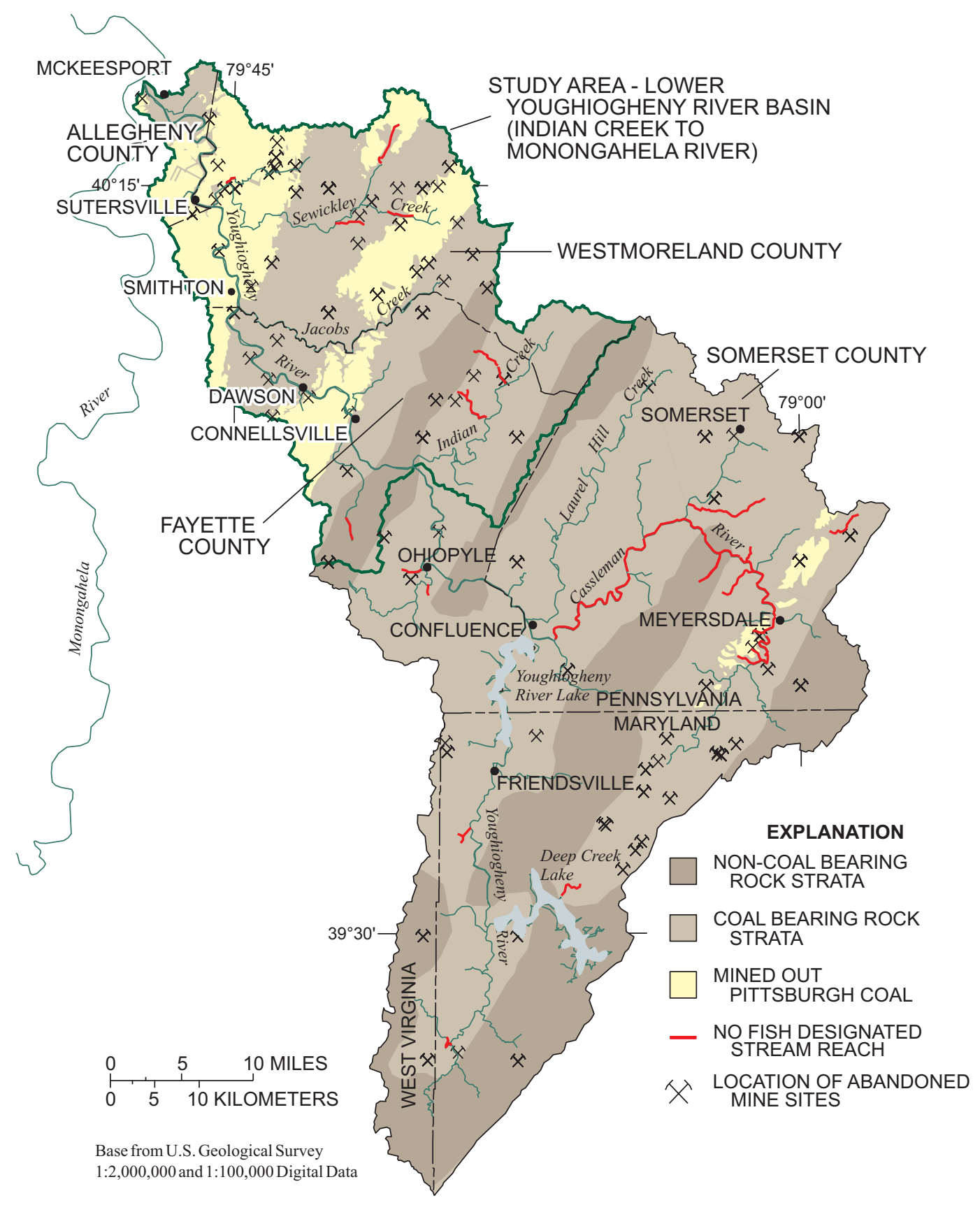

Figure 3. Rock strata in the Youghiogheny River Basin, Pennsylvania, Maryland, and West Virginia. 
Table 1. Summary of historical coal-mining activities from 1890 to 1998 by drainage basin within the Lower Youghiogheny River study area, Pennsylvania

\begin{tabular}{|c|c|c|c|c|c|c|c|}
\hline \multirow[b]{2}{*}{ Drainage basin } & \multicolumn{2}{|c|}{ Pre-1980 operations } & \multicolumn{3}{|c|}{ Post-1980 operations } & \multirow[b]{2}{*}{$\begin{array}{c}\text { Abandoned } \\
\text { mine lands } \\
\text { (number of } \\
\text { mines) }{ }^{1}\end{array}$} & \multirow[b]{2}{*}{$\begin{array}{c}\text { Number of } \\
\text { mine } \\
\text { discharges }\end{array}$} \\
\hline & $\begin{array}{l}\text { Number } \\
\text { of } \\
\text { surface } \\
\text { mines }^{2}\end{array}$ & $\begin{array}{l}\text { Number of } \\
\text { underground } \\
\text { mines }^{2}\end{array}$ & $\begin{array}{c}\text { Total } \\
\text { operations } \\
\text { (number of } \\
\text { mines) })^{2}\end{array}$ & $\begin{array}{l}\text { Under- } \\
\text { ground-mine } \\
\text { production } \\
\text { (thousands } \\
\text { of short } \\
\text { tons) }{ }^{2}\end{array}$ & $\begin{array}{l}\text { Surface- } \\
\text { mine } \\
\text { production } \\
\text { (thousands } \\
\text { of short } \\
\text { tons) }{ }^{2}\end{array}$ & & \\
\hline Indian Creek & 4 & 22 & 20 & 0 & 3,481 & 17 & 123 \\
\hline Laurel Run & 0 & 0 & 0 & 0 & 0 & 0 & 0 \\
\hline Dunbar Creek & 0 & 6 & 2 & 441 & 316 & 7 & 10 \\
\hline Connell Run & 0 & 0 & 0 & 0 & 0 & 0 & 0 \\
\hline Oppossum Run & 0 & 12 & 1 & 0 & 0 & 0 & 5 \\
\hline Mounts Creek & 0 & 5 & 1 & 0 & 1 & 1 & 9 \\
\hline Galley Run & 0 & 3 & 0 & 0 & 0 & 0 & 22 \\
\hline Hickman Run & 0 & 0 & 1 & 0 & 0 & 0 & 10 \\
\hline Dickerson Run & 0 & 2 & 0 & 0 & 0 & 0 & 3 \\
\hline Smiley Run & 0 & 0 & 0 & 0 & 0 & 0 & 0 \\
\hline Laurel Run & 0 & 0 & 1 & 0 & 145 & 0 & 0 \\
\hline Furnace Run & 0 & 0 & 0 & 0 & 0 & 1 & 0 \\
\hline Virgin Run & 0 & 0 & 0 & 0 & 0 & 0 & 0 \\
\hline Washington Run & 0 & 5 & 2 & 0 & 63 & 1 & 0 \\
\hline Browneller Run & 0 & 8 & 0 & 0 & 0 & 0 & 0 \\
\hline Jacobs Creek & 2 & 13 & 14 & 0 & 462 & 31 & 32 \\
\hline Cedar Creek & 0 & 8 & 0 & 0 & 0 & 0 & 0 \\
\hline Sewickley Creek & 2 & 159 & 17 & 313 & 514 & 67 & 75 \\
\hline Pollock Run & 3 & 33 & 1 & 0 & 0 & 3 & 0 \\
\hline Gillespie Run & 0 & 14 & 0 & 0 & 0 & 0 & 5 \\
\hline Crawford Run & 0 & 0 & 0 & 0 & 0 & 0 & 0 \\
\hline Long Run & 0 & 10 & 0 & 0 & 0 & 2 & 2 \\
\hline $\begin{array}{l}\text { Area near river } \\
\quad \text { (direct discharge) }\end{array}$ & 8 & 92 & 11 & 1,401 & 696 & 17 & 78 \\
\hline Total & 19 & 392 & 71 & 2,155 & 5,678 & 147 & 374 \\
\hline
\end{tabular}

${ }^{1}$ U.S. Office of Surface Mining, 1998.

2 Data on file at the offices of the U.S. Office of Surface Mining, U.S. Geological Survey, and the U.S. Environmental Protection Agency. 
Water-quality and flow data were requested, retrieved, and compiled from Federal and State agencies and private companies or organizations that had collected data at mine-discharge sites within the Lower Youghiogheny River Basin. Location (latitude and longitude) and water-quality and flow data from 1967 to 1998 for mine discharges were compiled from seven sources: Pennsylvania Department of Environmental Protection (written commun., 1998). Youghiogheny River Council (written commun., 1998), Regional Trails Corporation (written commun., 1998), Penn's Corner Resource Conservation and Development Area, U.S. Department of Agriculture (written commun., 1998), AmeriCorps (written commun., 1998), Western Pennsylvania Coalition for Abandoned Mine Reclamation (written commun., 1998), and Operation Scarlift (Gibbs \& Hill, Inc., 1971). The database of
374 mine discharges (table 1) varies in completeness, particularly with respect to water-quality and flow data. Every site contains latitude and longitude and source agency and where available, date sampled, flow volume, mine type, $\mathrm{pH}$, alkalinity, and concentrations of iron, manganese, aluminum, and sulfate. The sites represent unique locations; however, some sites may be duplicated in the database because no field verification was completed to check for duplicate sites. A duplicate site would be defined as one discharge represented by more than one site location.

At 104 of the 374 mine-discharge sites, both sulfate concentration and flow data were available. From these data, an instantaneous sulfate load in pounds per day was determined (fig. 4). Sulfate is the most available water-quality constituent in the database and is a

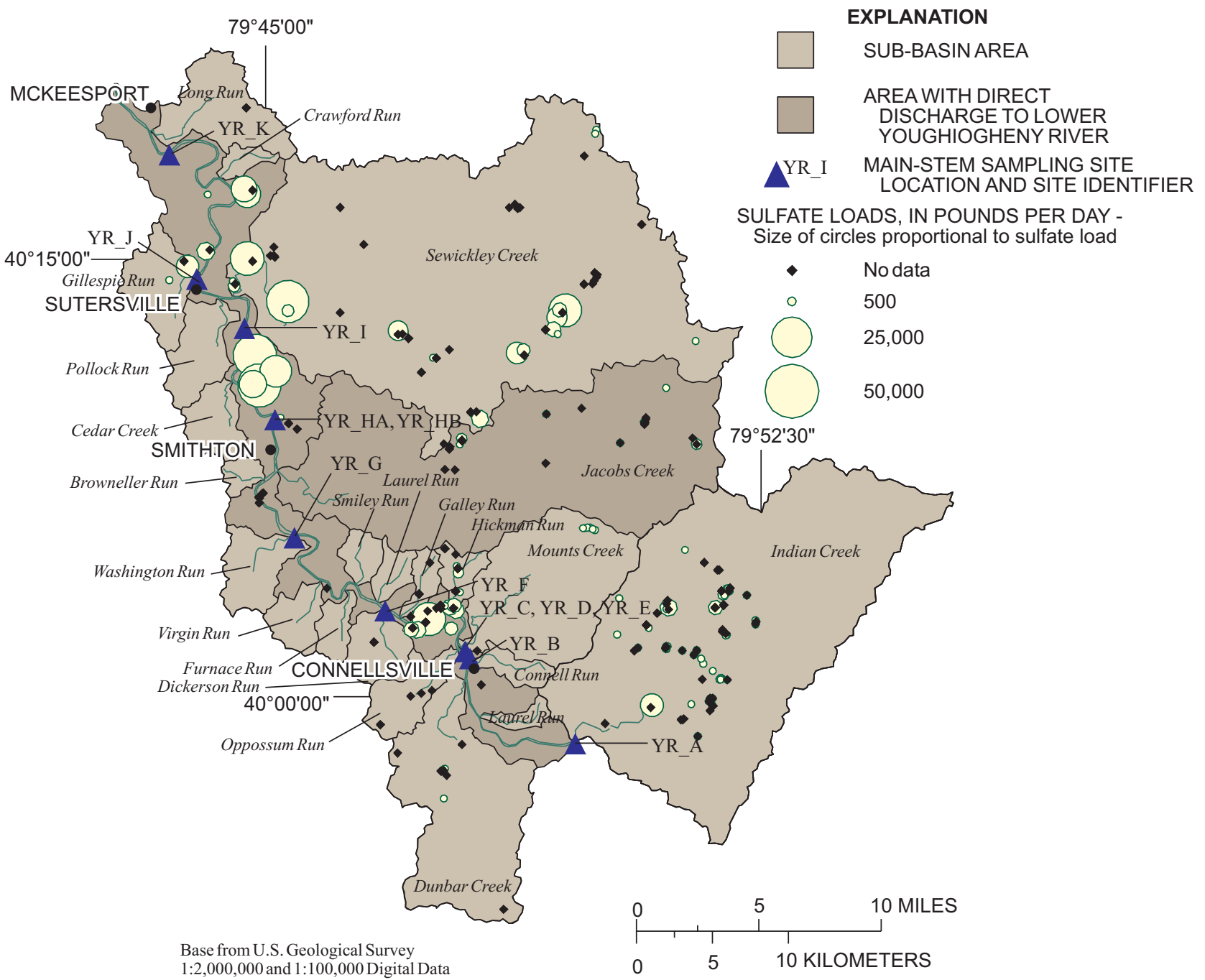

Figure 4. Historical sulfate loads from 104 mine discharges in the Lower Youghiogheny River Basin, Pennsylvania, 1967-98 (Locations of main-stem sites are listed in table 3). 
good indicator of mine drainage because it is a byproduct of the reaction of iron sulfide, exposed during mining, with air and water, and generally remains conserved in the drainage system (Hem, 1985). The distribution of historical sulfate loads for the 104 sites is summarized by subbasin to the Youghiogheny River Basin in figure 5. Ten sites (10 percent of the 104 sites) with the largest sulfate loads are listed in table 2.

Fifteen of the 104 mine-drainage sites with sulfate and flow data are in the area near the river (direct discharge, see fig. 4). These 15 sites discharging directly to the river had a median sulfate load of $5,000 \mathrm{lb} / \mathrm{d}$ (fig. 5). Seven of these 15 sites had sulfate loads ranging from 16,000 to $51,800 \mathrm{lb} / \mathrm{d}$ (table 2). These six mine discharges had an average flow of $5.03 \mathrm{ft}^{3} / \mathrm{s}$ and an average sulfate concentration of $1,193 \mathrm{mg} / \mathrm{L}$. Four of the seven sites are between the Youghiogheny River at Smithton (site YR_HA) and the Youghiogheny River at West Newton (site YR_I) (fig. 4). Three sites in the Sewickley Creek Basin had sulfate loads ranging from 26,500 to 49,600 lb/d (table 2). These three sites had an average flow of $6.8 \mathrm{ft}^{3} / \mathrm{s}$ and an average sulfate concentration of $967 \mathrm{mg} / \mathrm{L}$. Many of these sites also have elevated concentrations (above background levels) of iron and/or acidity (table 2 ).

The quality of these historical data is highly variable and conclusions utilizing these data should be made with caution. The water chemistry may have changed at the site since the data were collected or the site may no longer be present. The historical minedrainage sites were sampled at various times throughout the year (table 2) and under various hydrologic conditions. This sampling schedule can make an

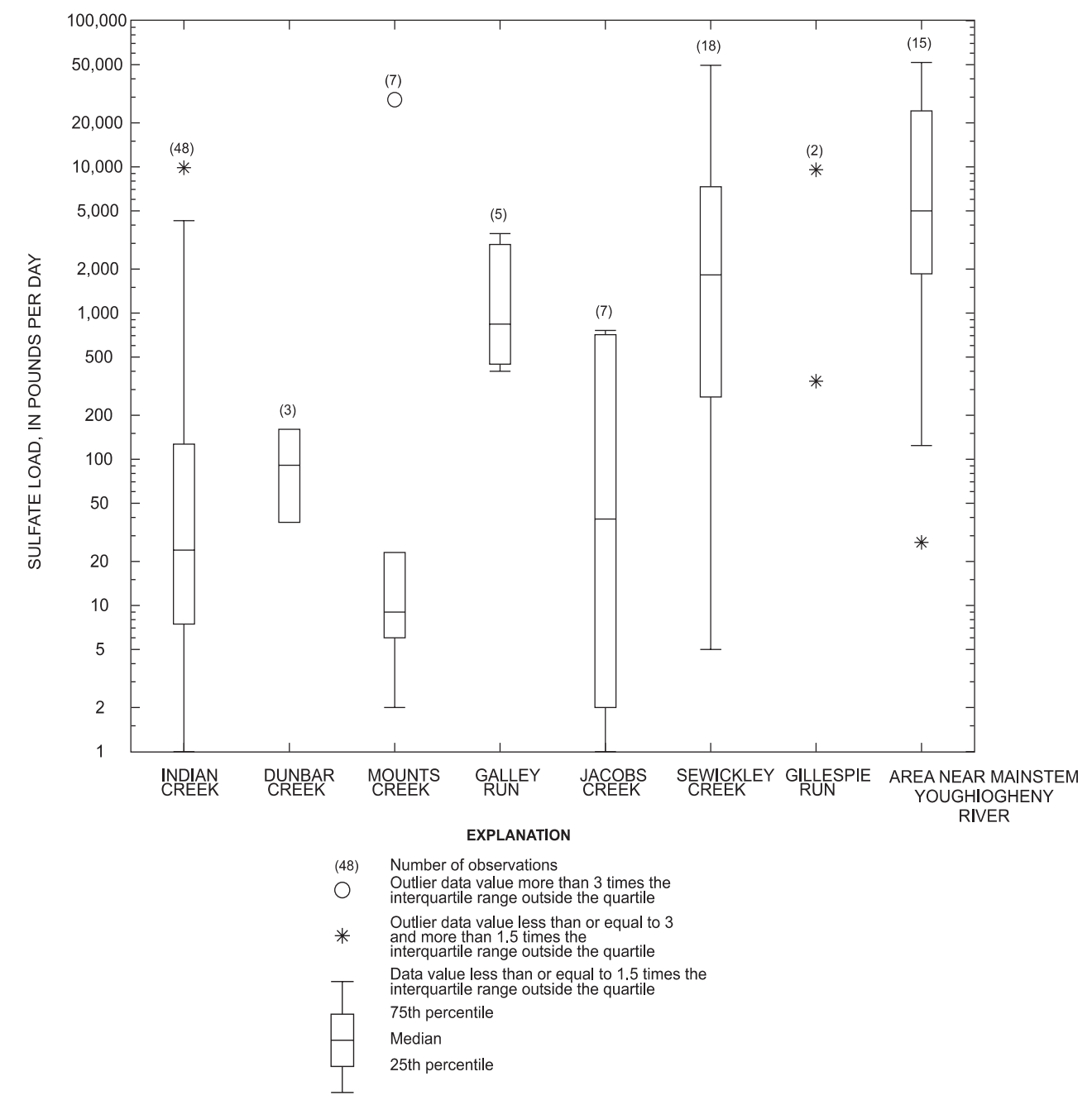

Figure 5. Distribution of historical sulfate loads for mine discharges by subbasins in the Lower Youghiogheny River Basin, Pennsylvania 1967-98. 
Table 2. Ten largest of 104 sulfate-load sites from historical mine-drainage database (1967-98) for the Lower Youghiogheny River Basin, Pennsylvania

[ft $\mathrm{t}^{3} / \mathrm{s}$, cubic feet per second; mg/L, milligrams per liter; lb/d, pounds per day; ND, no data]

\begin{tabular}{|c|c|c|c|c|c|c|c|c|c|c|}
\hline $\begin{array}{c}\text { Source of } \\
\text { information }^{1}\end{array}$ & $\begin{array}{l}\text { Mine-drainage } \\
\text { site identifier }\end{array}$ & $\begin{array}{l}\text { Receiving } \\
\text { stream }\end{array}$ & $\begin{array}{l}\text { Sample } \\
\text { date }\end{array}$ & $\begin{array}{c}\text { Instan- } \\
\text { taneous } \\
\text { flow } \\
\left(\mathrm{ft}^{3} / \mathrm{s}\right)\end{array}$ & $\begin{array}{l}\text { Field pH } \\
\text { (standard } \\
\text { units) }\end{array}$ & $\begin{array}{l}\text { Alkalinity } \\
\text { (mg/L) }\end{array}$ & $\begin{array}{l}\text { Acidity } \\
\text { (mg/L) }\end{array}$ & $\begin{array}{l}\text { Iron } \\
(\mathrm{mg} / \mathrm{L})\end{array}$ & $\begin{array}{l}\text { Sulfate } \\
(\mathrm{mg} / \mathrm{L})\end{array}$ & $\begin{array}{l}\text { Sulfate } \\
\text { load } \\
\text { (lb/d) }\end{array}$ \\
\hline $\begin{array}{c}\text { Pennsylvania } \\
\text { Department } \\
\text { of Environ- } \\
\text { mental } \\
\text { Protection }\end{array}$ & 401038794528 & Youghiogheny & $7 / 16 / 98$ & 5.57 & 6.8 & 538 & 0 & 30 & 1,723 & 51,800 \\
\hline $\begin{array}{l}\text { Pennsylvania } \\
\text { Department } \\
\text { of Environ- } \\
\text { mental } \\
\text { Protection }\end{array}$ & 401141794541 & Youghiogheny & $7 / 16 / 98$ & 5.57 & 6.8 & 520 & 0 & 32 & 1,706 & 51,300 \\
\hline $\begin{array}{l}\text { Operation } \\
\text { Scarlift }\end{array}$ & MD_13 & $\begin{array}{l}\text { Sewickley } \\
\text { Creek }\end{array}$ & $6 / 4 / 69$ & 6.33 & 5.3 & 0 & 320 & 67 & 1,450 & 49,600 \\
\hline AmeriCorps & MD_4 & Youghiogheny & $10 / 6 / 98$ & 6.20 & 6.6 & 295 & ND & 23 & 952 & 28,800 \\
\hline $\begin{array}{r}\text { Operation } \\
\text { Scarlift }\end{array}$ & MD_14 & $\begin{array}{l}\text { Sewickley } \\
\text { Creek }\end{array}$ & $6 / 2 / 69$ & 6.98 & 6.0 & 0 & 320 & 117 & 750 & 28,300 \\
\hline $\begin{array}{c}\text { Operation } \\
\text { Scarlift }\end{array}$ & MD_19 & Youghiogheny & $5 / 27 / 69$ & 8.56 & 6.5 & 0 & 80 & 89 & 597 & 27,600 \\
\hline $\begin{array}{r}\text { Operation } \\
\text { Scarlift }\end{array}$ & MD_12 & $\begin{array}{l}\text { Sewickley } \\
\text { Creek }\end{array}$ & $6 / 5 / 69$ & 7.09 & 6.1 & 80 & 300 & 123 & 700 & 26,500 \\
\hline $\begin{array}{r}\text { Operation } \\
\text { Scarlift }\end{array}$ & MD_17 & Youghiogheny & $6 / 9 / 69$ & 3.66 & 5.4 & 0 & 640 & 134 & 1,222 & 24,200 \\
\hline $\begin{array}{r}\text { Operation } \\
\text { Scarlift }\end{array}$ & MD_16 & Youghiogheny & $6 / 2 / 69$ & 3.20 & 7.6 & 100 & 0 & 0 & 931 & 16,100 \\
\hline $\begin{array}{c}\text { Operation } \\
\text { Scarlift }\end{array}$ & MD_03 & Youghiogheny & $6 / 10 / 69$ & 2.42 & 6.2 & 0 & 10 & 56 & 1,222 & 16,000 \\
\hline
\end{tabular}

${ }^{1}$ Pennsylvania Department of Environmental Protection, written commun., 1998; AmeriCorps, written commun., 1998; and Gibbs \& Hill, Inc., 1971.

appreciable difference in flow volume and, therefore, load estimates. Also, much of the data are from sites sampled 20 or more years ago, and the data may not be representative of current (1998) water-quality conditions. Methods used by the various collecting organizations are not uniform and quality-assurance data are either not available or have not been examined. The sulfate-load data and basin-wide analysis would be more representative if all 104 sites were sampled under the same hydrologic conditions by use of uniform methods. These limitations of the historical data point to the need for the present survey. Yet, even with the limitations, the historical data still are useful for defining historical conditions, in understanding the problem, for targeting potential problem areas, and for a qualitative evaluation of water-quality trends. 


\section{METHODS FOR THE CURRENT STUDY}

The study was designed to sample water from the main stem of the Lower Youghiogheny River from Connellsville, Pa., to McKeesport, Pa., and tributaries and mine discharges that enter the river between those points (fig. 6). Field crews from DOE and the USGS sampled water from 38 sites during a 3-day period (October 5, 6, and 7, 1998) when low-flow conditions prevailed uniformly throughout the sampling area. Personnel from the Regional Trails Corporation, Pennsylvania Department of Environmental Protection, and AmeriCorps also supported the field effort. Of the 38 sites sampled, 12 were main-stem sites on the Youghiogheny River (YR), 22 were tributary streams (TR) flowing into the Youghiogheny River, and 4 were mine discharges (MD) flowing directly into the Youghiogheny River (table 3, fig. 6). Tributaries were sampled near the mouth but upstream of any backwater from the main stem.

Sites on the main stem of the Youghiogheny River were selected, in part, on the basis of bridge locations. Bridges are convenient access points to the river and allow for easy water-quality sampling. Consequently, three main-stem sampling sites (YR_C, YR_D, and YR_E) immediately downstream from Connellsville are close together (within about $600 \mathrm{ft}$; fig. 6). Two other sites, YR_HA and YR_HB, were also very close together (fig. 6). These two sites were selected to evaluate any input from a suspected seep into the streambed between the two sampling sites.

Streamflow, $\mathrm{pH}$, specific conductance, water temperature, and dissolved-oxygen concentration were measured at each sampling location. Field methods followed guidelines set forth for the USGS National Water-Quality Assessment Program (Shelton, 1994). The samples were transported to a centralized field location where alkalinity was determined. An unfiltered, non-acidified and a filtered, acidified sample were prepared and transported to the DOE analytical laboratory in Pittsburgh, Pa. Field blank samples and duplicate samples for quality-control checks were prepared in a similar fashion. In the laboratory, $\mathrm{pH}$, alkalinity, and acidity were measured, and the concentration of each of the following ions was determined by use of inductively coupled plasma-atomic emission spectroscopy (ICP-AES) analytical metho- dology following established procedures (U.S. Environmental Protection Agency, 1983; Eaton and others, 1995; Fales and Kenny, 1940): $\mathrm{Fe}_{\text {TOT, }} \mathrm{Al}, \mathrm{As}, \mathrm{Ba}$, $\mathrm{Be}, \mathrm{Ca}, \mathrm{Cd}, \mathrm{Co}, \mathrm{Cu}, \mathrm{K}, \mathrm{Mg}, \mathrm{Mn}, \mathrm{Na}, \mathrm{Ni}, \mathrm{Pb}, \mathrm{Sb}, \mathrm{SO}_{4}$, $\mathrm{Se}, \mathrm{Zn}$ (table 4). Ferrous iron $\left(\mathrm{Fe}^{2+}\right)$ was determined by titration with $\mathrm{K}_{2} \mathrm{Cr}_{2} \mathrm{O}_{4}$ (Fales and Kenny, 1940).

Quality-assurance measures included depth- and width-integrated sampling at the main-stem sites. Duplicate field samples were collected at two sites. Variation between the duplicate samples was small; no constituent had a significant deviation between the environmental sample and the duplicate sample. Values for all chemical species analyzed in two blank samples were less than the detection limit indicating no contamination in the sampling or analytical procedures. Blind reference samples ${ }^{1}$ analyzed by the DOE laboratory indicated good accuracy. Values for these reference samples analyzed by DOE were within the expected values for all chemical species analyzed.

There was good agreement between field and laboratory $\mathrm{pH}$ measurements. The field and laboratory values ranged from 5.8 to 8.5 ; the field and laboratory medians were 7.6 and 7.8 , respectively.

Sample alkalinity ranged from 15 to $320 \mathrm{mg} / \mathrm{L}$ as $\mathrm{CaCO}_{3}$. In general, values for field and laboratory alkalinities nearly were identical and there was no indication of a negative bias for the laboratory analyses, which would occur if the samples aged appreciably during storage and transportation. Linear regression analysis comparing field and laboratory alkalinity values gave a slope of 1.00 , an intercept of $0.02 \mathrm{mg} / \mathrm{L}$, and an $\mathrm{r}^{2}$ of 0.98 , indicating strong correlation.

\footnotetext{
${ }^{1}$ Blind samples are samples submitted for analysis whose composition is known to the submitter but unknown to the analyst. Blind samples can be used to monitor the performance of an analytical system, check the analytical results of more than one laboratory, more than one analytical method, or the consistency of the same laboratory and method. Blind samples may be prepared from a reference material-a material or substance one or more properties of which are sufficiently well established to be used for the assessment of a measurement method or for assigning values to materials
} 


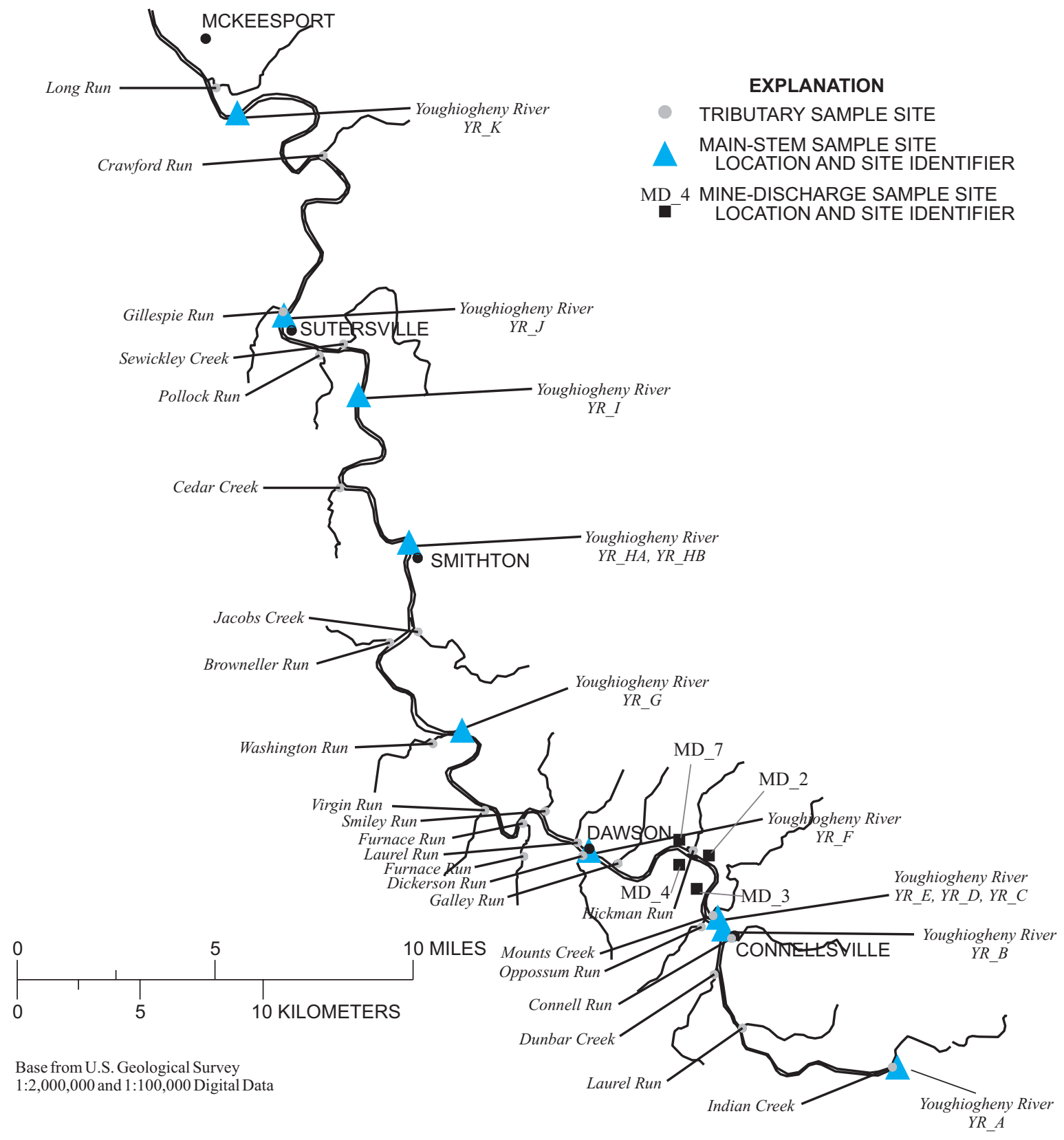

Figure 6. Locations of main-stem, tributary, and mine-discharge sampling sites in the Lower Youghiogheny River Basin, Pennsylvania, October 5-7, 1998. 
Table 3. Main-stem, tributary, and mine-discharge sampling sites for the Lower Youghiogheny River Basin synoptic survey, Pennsylvania, October 5-7, 1998

$[-$, not applicable $]$

\begin{tabular}{|c|c|c|c|c|c|}
\hline $\begin{array}{c}\text { Site } \\
\text { identifier }\end{array}$ & Latitude & Longitude & Stream name & Location & $\begin{array}{c}\text { Drainage } \\
\text { area } \\
\text { (square } \\
\text { miles) }\end{array}$ \\
\hline \multicolumn{6}{|c|}{ Main-stem river sites } \\
\hline YR_A & 395803 & 793043 & Youghiogheny River & upstream from Indian Creek & 1,140 \\
\hline YR_B & 400103 & 793538 & Youghiogheny River & at USGS streamflow-gaging station, Connellsville & 1,330 \\
\hline YR_C & 400118 & 793551 & Youghiogheny River & at Rt. 119 bridge, Connellsville & 1,330 \\
\hline YR_D & 400221 & 793744 & Youghiogheny River & Downstream Rt. 119 Bridge, 100 meters & 1,330 \\
\hline YR_E & 400210 & 793805 & Youghiogheny River & Downstream of site YR_D, 100 meters & 1,330 \\
\hline YR_F & 400244 & 793935 & Youghiogheny River & at Rt. 819 Bridge, Dawson & 1,370 \\
\hline YR_G & 400518 & 794349 & Youghiogheny River & at Rt. 4038 Bridge, Layton & 1,410 \\
\hline YR_HA & 400926 & 794441 & Youghiogheny River & at Rt. 981 Bridge, Smithton & 1,520 \\
\hline YR_HB & 400926 & 794441 & Youghiogheny River & Downstream of site YR_HA, 100 meters & 1,520 \\
\hline YR_I & 401240 & 794610 & Youghiogheny River & at Rt. 136 Bridge, West Newton & 1,530 \\
\hline YR_J & 401424 & 794824 & Youghiogheny River & at USGS streamflow-gaging station, Sutersville & 1,710 \\
\hline YR_K & 401846 & 794942 & Youghiogheny River & at Rt. 48 Bridge, Boston & 1,740 \\
\hline \multicolumn{6}{|c|}{ Tributary sites } \\
\hline TR_1 & 395807 & 793048 & Indian Creek & near mouth & 125 \\
\hline TR_2 & 395858 & 793507 & Laurel Run & near mouth & 1.82 \\
\hline TR_3 & 400008 & 793556 & Dunbar Creek & near mouth & 36.9 \\
\hline TR_4 & 400055 & 793526 & Connell Run & near mouth & 3.13 \\
\hline TR_5 & 400110 & 793618 & Opossum Run & near mouth & 7.17 \\
\hline TR_6 & 400125 & 793558 & Mounts Creek & near mouth & 31.2 \\
\hline TR_7 & 400250 & 793632 & Galley Run & near mouth & 3.26 \\
\hline TR_8 & 400233 & 793842 & Hickman Run & near mouth & 2.60 \\
\hline TR_9 & 400234 & 793748 & Dickerson Run & near mouth & 6.05 \\
\hline TR_10 & 400300 & 793952 & Smiley Run & near mouth & 2.71 \\
\hline TR_11 & 400341 & 794048 & Laurel Run & near mouth & 2.91 \\
\hline TR_12 & 400242 & 794125 & Furnace Run & near mouth & 3.17 \\
\hline TR_13 & 400342 & 794233 & Virgin Run & near mouth & 4.72 \\
\hline TR_14 & 400509 & 794403 & Washington Run & near mouth & 7.75 \\
\hline TR_15 & 400721 & 794518 & Browneller Run & near mouth & 1.94 \\
\hline TR_16 & 400735 & 794429 & Jacobs Creek & near mouth & 94.8 \\
\hline TR_17 & 401043 & 794645 & Cedar Creek & near mouth & 5.72 \\
\hline TR_18 & 401351 & 794639 & Sewickley Creek & near mouth & 168 \\
\hline TR_19 & 401336 & 794721 & Pollock Run & near mouth & 8.10 \\
\hline TR_20 & 401433 & 794824 & Gillespie Run & near mouth & 9.08 \\
\hline TR_21 & 401757 & 794715 & Crawford Run & near mouth & 1.97 \\
\hline TR_22 & 401925 & 795021 & Long Run & near mouth & 13.2 \\
\hline \multicolumn{6}{|c|}{ Mine discharges flowing directly into the Youghiogheny River } \\
\hline MD_2 & 400239 & 793613 & - & at mine discharge & - \\
\hline MD_3 & 400235 & 793628 & - & at mine discharge & - \\
\hline MD_4 & 400221 & 793741 & - & at mine discharge & - \\
\hline MD_7 & 400242 & 793619 & 一 & at mine discharge & - \\
\hline
\end{tabular}


Table 4. Constituents analyzed for in the laboratory and the method reporting limits used for this study in the Lower Youghiogheny River Basin

[Reporting limits are in milligram per liter]

\begin{tabular}{clc}
\hline $\begin{array}{c}\text { Chemical } \\
\text { symbol }\end{array}$ & \multicolumn{1}{c}{ Constituent } \\
name & $\begin{array}{c}\text { Department of } \\
\text { Energy } \\
\text { laboratory } \\
\text { method reporting } \\
\text { limit }\end{array}$ \\
\hline $\mathrm{Fe}^{2+}$ & Ferrous iron as Fe & 1 \\
$\mathrm{Fe}_{\mathrm{TOT}}$ & Total iron as Fe & .02 \\
$\mathrm{Ca}$ & Calcium as $\mathrm{Ca}$ & .04 \\
$\mathrm{Mg}$ & Magnesium as $\mathrm{Mg}$ & .04 \\
$\mathrm{Al}$ & Aluminum as $\mathrm{Al}$ & .04 \\
$\mathrm{Na}$ & Sodium as $\mathrm{Na}$ & .1 \\
$\mathrm{Mn}$ & Manganese as $\mathrm{Mn}$ & .006 \\
$\mathrm{SO} 4$ & Sulfate as $\mathrm{SO}$ & .1 \\
$\mathrm{~K}$ & Potassium as $\mathrm{K}$ & .1 \\
$\mathrm{As}$ & Arsenic as $\mathrm{As}$ & .08 \\
$\mathrm{Ba}$ & Barium as $\mathrm{Ba}$ & .01 \\
$\mathrm{Be}$ & Beryllium as $\mathrm{Be}$ & .001 \\
$\mathrm{Cd}$ & Cadmium as $\mathrm{Cd}$ & .006 \\
$\mathrm{Co}$ & Cobalt as $\mathrm{Co}$ & .006 \\
$\mathrm{Cu}$ & Copper as $\mathrm{Cu}$ & .01 \\
$\mathrm{Ni}$ & Nickel as $\mathrm{Ni}$ & .01 \\
$\mathrm{~Pb}$ & Lead as $\mathrm{Pb}$ & .08 \\
$\mathrm{Sb}$ & Antimony as $\mathrm{Sb}$ & .08 \\
$\mathrm{Se}$ & Selenium as Se & .1 \\
$\mathrm{Zn}$ & Zinc as $\mathrm{Zn}$ & .006 \\
\hline
\end{tabular}

\section{HYDROLOGIC AND WATER-QUALITY CONDITIONS MEASURED DURING LOW FLOW}

\section{Hydrologic Conditions}

The streams in the Lower Youghiogheny River Basin during this survey were considered to be at a low-flow condition on the basis of flow-duration analyses at the USGS streamflow-gaging stations at Connellsville and Sutersville. The streamflow at Connellsville (site YR_B) at the time the water sample was collected was $722 \mathrm{ft}^{3} / \mathrm{s}$ (10:10 a.m., Oct. 6, 1998) (fig. 7). The flow-duration analysis for water years ${ }^{1}$ 1987 through 1998 shows a flow of $722 \mathrm{ft}^{3} / \mathrm{s}$ at this site is equalled or exceeded about 90 percent of the time. The streamflow for the Youghiogheny River at Suters-

\footnotetext{
${ }^{1}$ Water year as used in U.S. Geological Survey reports, is the 12-month period October 1 through September 30. The water year is designated by the calendar year in which it ends and which includes 9 of the 12 months. Thus, the year ending September 30, 2000 , is called the "2000 water year."
}

ville (site YR_J) was $812 \mathrm{ft}^{3} / \mathrm{s}$ at the time of sample collection (2:05 p.m., Oct. 6, 1998) (fig. 7). This streamflow is exceeded 90 percent of the time at Sutersville.

The streamflows measured at each main-stem site during this study were compared to calculated streamflows - the sum of the measured streamflow at the closest upstream main-stem site plus the flow measured for any tributaries flowing into the Youghiogheny River between the two sites (fig. 7). Site YR_A was not used because it may have been under the effect of a previous rain and, therefore, not at low-base-flow conditions. Measured streamflow at site YR_E $\left(788 \mathrm{ft}^{3} / \mathrm{s}\right)$ is much larger than the calculated flow $\left(708 \mathrm{ft}^{3} / \mathrm{s}\right)$ for this site. This difference, or unaccounted for gain in streamflow, could be from water entering the streambed from abandoned underground mining operations. However, this site is only $300 \mathrm{ft}$ downstream from site YR_D, and there are no known inputs between the two sites. Further, the measured streamflow at site YR_E is appreciably different from other measured flows in this stream reach and, therefore, is assumed to be in error. The difference between measured flow at this site and the next upstream site is $80 \mathrm{ft}^{3} / \mathrm{s}$, or about 10 percent of the flow volume. Measurement errors of this magnitude (10 percent) are expected occasionally and the accuracy is considered "good" (Siwicki, 2001, p. 12). A re-measurement of streamflows in this reach could clarify the results. Alternatively, remote sensing using thermal infrared imaging could be used to verify that no seeps are entering the streambed in this reach or to identify unknown input sources.

The measured streamflow was smaller than the calculated flow at sampling site YR_F (fig. 7). At this site, the difference, or unaccounted for loss, is attributable to the error in streamflow measurement at the upstream site YR_E. Because calculated flows are the sum of measured flow at the closest upstream site and measured flows of the tributaries, an error in measurement at the upstream site would result in an error in the calculated flow for the next site downstream. This result is believed to be the case for site YR_F.

Unaccounted for losses in streamflow also might be attributed to water loss through streambed fractures. This hypothesis has validity because of extensive mine tunnels that exist in this region. These tunnels traverse this section of the Youghiogheny River under the streambed. Loss of water from the river to these underground tunnels and mine pools seems likely. If this water loss occurs, the water quality would be degraded as the relatively clean river water enters the under- 


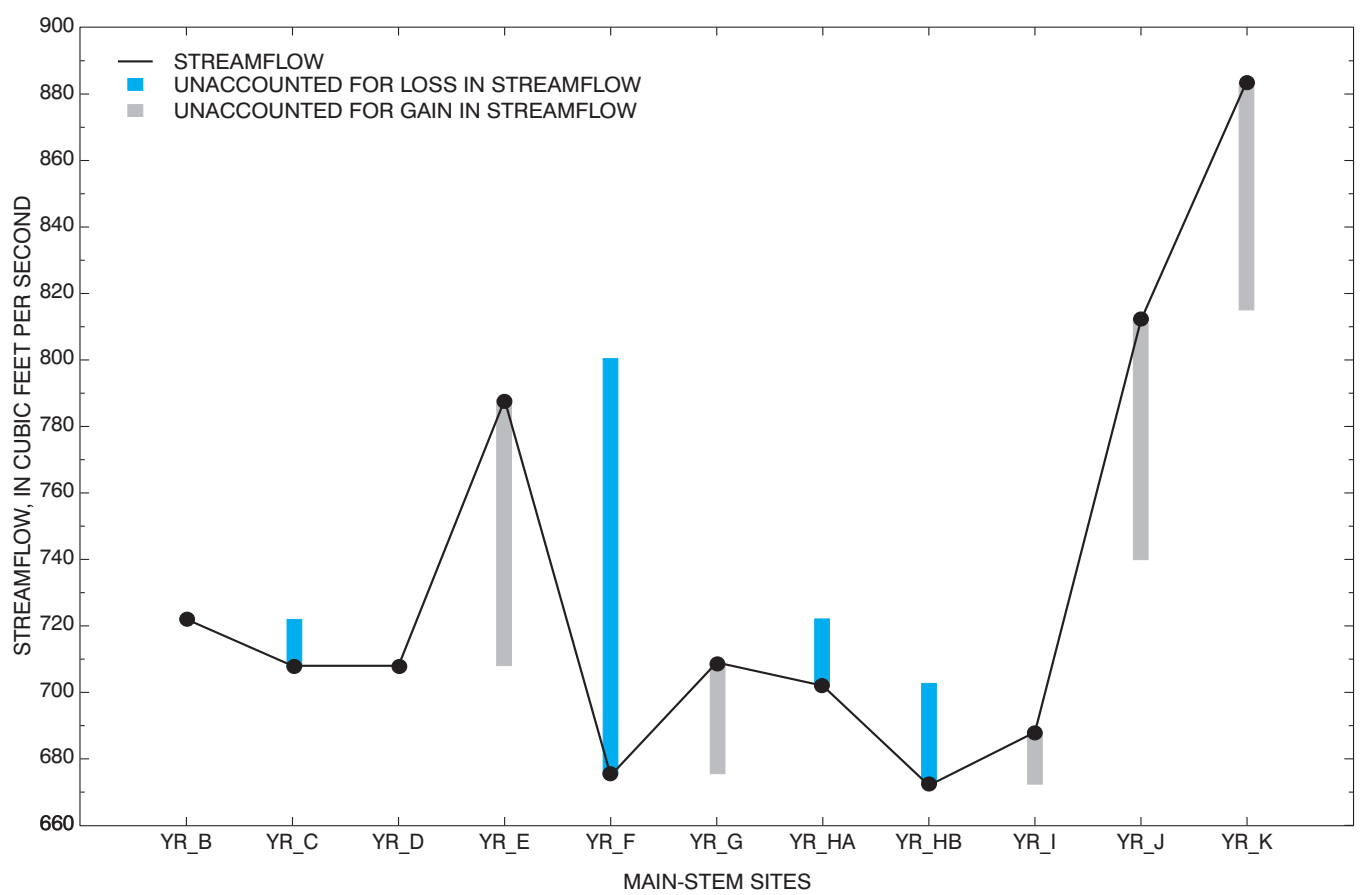

Figure 7. Streamflows and unaccounted for gains and losses in main-stem sites during the synoptic survey in the Lower Youghiogheny River Basin, Pennsylvania, October 5-7, 1998. (The unaccounted for gains or losses are determined by subtracting a calculated streamflow at a sitethe sum of the measured streamflow at the closest upstream main-stem site plus the flow measured for any tributaries flowing into the Youghiogheny River between the two sites-from the measured streamflow.)

ground mine pools and comes in contact with iron pyrite disturbed in the historical mining operations. Eventually, this underground water, having degraded water quality, could return to the river in the form of downstream seeps or through springs and tributaries.

Differences between measured and calculated flows in the reach of the Lower Youghiogheny River from sampling site YR_G through YR_I are small (fig. 7) and probably are within the ability to accurately measure streamflow. Under ideal conditions, manual streamflow-measurement techniques used routinely by the USGS are estimated to be accurate to within +/- 2.2 percent, two-thirds of the time (Rantz and others, 1982). The conditions for measuring streamflow during the survey were good (low flow, relatively uniform cross-sections), but measurement conditions varied from site to site. To obtain an understanding of the possible effect of measurement error, assume that measurement error during the Lower Youghiogheny River survey was 5 percent. During the survey, streamflow was measured at about $750 \mathrm{ft}^{3} / \mathrm{s}$. Five percent of $750 \mathrm{ft}^{3} / \mathrm{s}$ is $37.5 \mathrm{ft}^{3} / \mathrm{s}$. Thus, differences between measured and calculated flow at sampling sites YR_C, YR_G, YR_HA, YR_HB, and YR_I may be the result of measurement error. But, larger differences at sampling sites YR_J and YR_K cannot be explained by measurement error. At the downstream sampling sites YR_J and YR_K, measured flows were larger than calculated flows (fig. 7). These discrepancies or unaccounted for gains represent inputs not measured in the survey. Although some water may come from unmeasured tributaries and/or surface seeps, most of the discrepancy is suspected to come from artesian flow through fractures in the streambed from underground mine pools. This section of the Lower Youghiogheny River has extensive underground mine workings. Influent flows of rust-colored water were noted in some river sections, lending support to this hypothesis.

Streamflow losses and gains may be identified by a flow-duration analysis. A flow-duration curve indicates factors affecting basin hydrology such as rainfall/ runoff relations and ground-water recharge (Searcy, 1959). Flow-duration curves for the Youghiogheny 
River at Connellsville (YR_B) and the Youghiogheny River at Sutersville (YR_J) are shown on figure 8. The streamflow is normalized by drainage area in order to compare the two stations. At 90-percent exceedence, the Youghiogheny River at Connellsville has a discharge of $0.55\left[\mathrm{ft}^{3} / \mathrm{s} / \mathrm{mi}^{2}\right]$. This streamflow is 15 percent more than the $0.47\left[\mathrm{ft}^{3} / \mathrm{s} / \mathrm{mi}^{2}\right]$ at the Youghiogheny River at Sutersville. The relative difference in streamflow between the two stations increases as streamflow decreases (8-percent difference at 10-percent exceedence and 15-percent difference at 90-percent exceedence). The Youghiogheny River at Sutersville appears to be a losing reach when compared to Connellsville. These differences may be a result of differences in geology and soil conditions in the lower part of the basin. Another possible cause is streamflow lost through fractures, which could be a result of underground coal mining. Streamflow lost through fractures in the river channel can enter underground mines. This water, contaminated with mine drainage, then can eventually reenter the river through the channel bottom at downstream locations. However, the chemical analyses do not support this hypothesis. Loads of alkalinity, sulfate, and major ions all indicate the reach of the Youghiogheny River at Sutersville is receiving unmeasured inputs from the underground mines rather than losing water to them. Unaccounted for water withdrawals, a change in historical conditions, or temporary hydrologic conditions at low flow

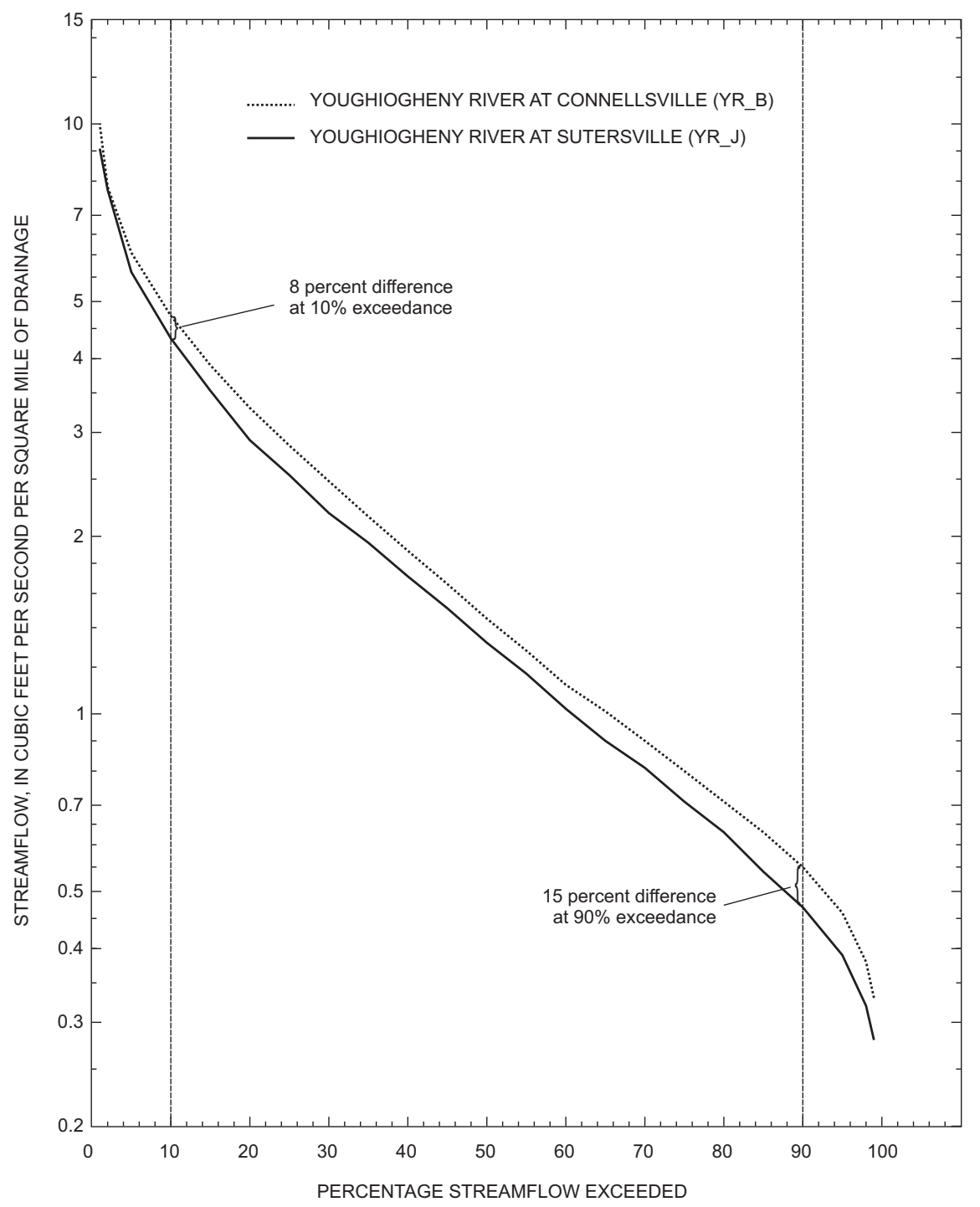

Figure 8. Flow-duration curves for the Youghiogheny River at Connellsville and Sutersville, Pennsylvania, for water years 1987-98. 
could account for these apparent differences. These differences emphasize the need for corroborative evidence such as could be obtained from remote-sensing techniques.

Data from periodic staff-gage readings and permanent streamflow-gaging stations (at Connellsville and Sutersville) have shown the surface-water and ground-water hydrology in this study area are complex. This complexity may be partially due to past mine activities as well as fractures in the streambed. Because streamflow in the river is usually large relative to the discharge from the fractures beneath the streambed, gaging cannot be used in most cases to locate any fracture-controlled discharges in the streambed. For the same reasons, it is at best extremely difficult, if not impossible, because of dilution, to use chemical analysis to locate them. Other techniques are needed. Remote sensing techniques being tested by DOE's NETL may prove to be valuable in unraveling the complexities of inputs and losses to streambed fractures.

\section{Water-Quality Conditions}

The Youghiogheny River drains an area having a multitude of active and inactive mining operations. Yet, remarkably, the water quality in the Lower Youghiogheny River is reasonably good. Measured $\mathrm{pH}$ values were greater than 7.0 for all main-stem sites (table 5). The lowest $\mathrm{pH}$ measured during the survey was 5.8 in Galley Run. Every sampling site, including the main stem, tributaries, and mine discharges, had net alkalinity (alkalinity concentrations in the sample were higher than the acidity concentrations, based on calculated acidity values). However, at two main-stem sites and six tributary sites, concentrations of dissolved and total iron, manganese, and/or aluminum exceeded water-quality standards or criteria. Water-quality standards were exceeded at all four mine-discharge sites.

\section{pH}

The $\mathrm{pH}$ values for all the samples collected during this survey were above 5.8 and most (33 of 38 sites) were above 7.0 (table 5). Even the mine-discharge sites had $\mathrm{pH}$ values between 6.3 and 6.7. The natural buffering capacity in the basin is sufficient to maintain a circumneutral $\mathrm{pH}$, at least under these low-flow conditions, despite the acid-producing reactions taking place. Under these conditions, the rate of ferrous ion oxidation is inversely proportional to the square of the hydrogen-ion concentration; thus, the $\mathrm{pH}$ is important in the capability of a stream to naturally remove the iron (Stumm and Morgan, 1996).

\section{Alkalinity}

Alkalinity, which is usually expressed in terms of an equivalent calcium carbonate $\left(\mathrm{CaCO}_{3}\right)$ concentration, is a measure of the buffering capacity of the stream. Alkalinity neutralizes the acid produced by the mine drainage. The presence of alkalinity indicates the water has percolated through carbonate-bearing strata such as limestone or a mineral carbonate (or hydroxide) has been added by human activity such as the water-treatment technologies used by active mines. Neutralizing the acid also enhances the oxidation of ferrous iron because the oxidation rate of ferrous iron is a linear function of $\mathrm{pH}$ for $\mathrm{pH}$ values higher than about $4.5 \mathrm{pH}$ units (Stumm and Morgan, 1996). Large limestone deposits in the Youghiogheny River Basin undoubtedly are important in promoting the natural remediation of mine discharges.

The measured alkalinity load in the Youghiogheny River between Connellsville (site YR_B) and McKeesport (site YR_K) increased from 35 to 79 ton/d (fig. 9). Upstream from site YR_HB, measured alkalinity loads were similar to calculated alkalinity loads (the sum of the measured alkalinity load at the closest upstream main-stem site plus the loads measured for any tributaries flowing into the Youghiogheny River between the two sites) (fig. 9). Downstream from site YR_HB, the measured and calculated loads did not agree closely. Measured alkalinity loads are larger than calculated loads at sampling sites YR_I and YR_K, resulting in unaccounted for gains in alkalinity load. These gains in alkalinity load are believed to be from seeps in the streambed.

At site YR_J, the unaccounted for loss in alkalinity load is about 10 ton/d (fig. 9). Sewickley Creek enters the Youghiogheny River between sites YR_I and YR_J. Even though Sewickley Creek is affected by mine drainage, the stream is net alkaline and delivers a large alkalinity load to the river (14 ton/d). However, the measured alkalinity load is smaller than the calculated load, resulting in an unaccounted for loss in alkalinity load at site YR_J. Alkalinity is not conservative but is chemically reactive. The alkalinity could be lost when ferrous iron from Sewickley Creek is oxidized to ferric iron in the Youghiogheny River. The equation that governs this reaction is

$$
\begin{gathered}
\mathrm{Fe}^{2+}+1 / 4 \mathrm{O}_{2}+1 / 2 \mathrm{H}_{2} \mathrm{O}+2 \mathrm{HCO}_{3}^{-} \\
\stackrel{\rightarrow}{\rightarrow} \mathrm{Fe}(\mathrm{OH})_{3}+2 \mathrm{CO}_{2}
\end{gathered}
$$




\begin{tabular}{|c|c|c|c|c|c|c|c|c|c|c|c|c|c|c|c|}
\hline $\begin{array}{l}\text { Table } 5 . \\
\text { tributary, } \\
{\left[\mathrm{ft}^{3} / \mathrm{s}, \mathrm{cubi}\right.} \\
--, \text { not app }\end{array}$ & $\begin{array}{l}\text { Field measure } \\
\text { and mine-disc } \\
\text { feet per secon } \\
\text { licable] }\end{array}$ & $\begin{array}{l}\text { ents of physical } \\
\text { rge sites in the } L \\
{ }^{C} \text {, degrees Celsiu }\end{array}$ & $\begin{array}{l}\text { operties } \\
\text { wer You } \\
\mu \mathrm{S} / \mathrm{cm}, \mathrm{r}\end{array}$ & $\begin{array}{l}\text { nd co } \\
\text { iogh } \\
\text { rosie }\end{array}$ & $\begin{array}{l}\text { nstituents a } \\
\text { ny River } B \\
\text { nens per cen }\end{array}$ & $\begin{array}{l}\text { id results } \\
\text { sin, Pen } \\
\text { imeter at }\end{array}$ & $\begin{array}{l}\text { of chemic } \\
\text { sylvania, } \\
5 \text { degrees }\end{array}$ & $\begin{array}{l}\text { al analys } \\
\text { Jctober } \\
\text { Celsius; } m\end{array}$ & $\begin{array}{l}\text { es for maj } \\
-7,1998 \\
\text { g/L, milligra }\end{array}$ & ions for & $\begin{array}{l}\text { later sal } \\
\text { USGS, U }\end{array}$ & Sples cc & caled $f$ & $\begin{array}{l}m \text { main } \\
\mathrm{y} ;<\text {, les }\end{array}$ & $\begin{array}{l}\text { stem, } \\
\text { than; }\end{array}$ \\
\hline $\begin{array}{c}\text { Site } \\
\text { identifier }\end{array}$ & $\begin{array}{l}\text { Stream } \\
\text { name }\end{array}$ & Location & Date & Time & $\begin{array}{l}\text { Instan- } \\
\text { taneous } \\
\text { streamflow } \\
\left(\mathrm{ft}^{3} / \mathrm{s}\right)\end{array}$ & $\begin{array}{l}\text { Water } \\
\text { temper- } \\
\text { ature } \\
\left({ }^{\circ} \mathrm{C}\right)\end{array}$ & $\begin{array}{l}\text { Dissolved } \\
\text { oxygen } \\
\text { (mg/L) }\end{array}$ & $\begin{array}{c}\text { Specific } \\
\text { conduc- } \\
\text { tance } \\
(\mu \mathrm{S} / \mathrm{cm})\end{array}$ & $\begin{array}{l}\text { Field } \\
\text { pH } \\
\text { (standard } \\
\text { units) }\end{array}$ & $\begin{array}{l}\text { Alkalinity, } \\
\text { total field } \\
(\mathrm{mg} / \mathrm{L} \text { as } \\
\left.\mathrm{CaCO}_{3}\right)\end{array}$ & $\begin{array}{l}\text { Sulfate } \\
(\mathrm{mg} / \mathrm{L})\end{array}$ & $\begin{array}{l}\text { Calcium } \\
\text { (mg/L) }\end{array}$ & $\begin{array}{l}\text { Magne- } \\
\text { sium } \\
(\mathrm{mg} / \mathrm{L})\end{array}$ & $\begin{array}{l}\text { Sodium } \\
(\mathrm{mg} / \mathrm{L})\end{array}$ & $\begin{array}{l}\text { Potas- } \\
\text { sium } \\
(\mathrm{mg} / \mathrm{L})\end{array}$ \\
\hline \multicolumn{16}{|c|}{ Main-stem sites } \\
\hline YR_A & $\begin{array}{l}\text { Youghiogheny } \\
\text { River }\end{array}$ & $\begin{array}{l}\text { upstream from } \\
\text { Indian Creek }\end{array}$ & $10 / 05 / 98$ & 1600 & 827 & 18.5 & 10.2 & 125 & 7.3 & 16 & 33 & 14 & 3.73 & 5.4 & 1.4 \\
\hline YR_B & $\begin{array}{l}\text { Youghiogheny } \\
\text { River }\end{array}$ & $\begin{array}{l}\text { at USGS } \\
\text { streamflow- } \\
\text { gaging station, } \\
\text { Connellsville }\end{array}$ & $10 / 06 / 98$ & 1010 & 722 & 17.0 & 10.2 & 137 & 7.1 & 18 & 37 & 16 & 4.21 & 5.6 & 1.4 \\
\hline YR_C & $\begin{array}{l}\text { Youghiogheny } \\
\text { River }\end{array}$ & $\begin{array}{l}\text { at Rt. } 119 \text { Bridge, } \\
\text { Connellsville }\end{array}$ & $10 / 06 / 98$ & 0930 & 708 & 16.5 & 8.8 & 156 & 7.6 & 18 & 37 & 16 & 4.10 & 5.6 & 1.4 \\
\hline YR_D & $\begin{array}{l}\text { Youghiogheny } \\
\text { River }\end{array}$ & $\begin{array}{l}\text { Downstream } \\
\text { Rt. } 119 \text { Bridge, } \\
100 \text { meters }\end{array}$ & $10 / 06 / 98$ & 1015 & 708 & 17.5 & 10.2 & 138 & 7.6 & 18 & 37 & 16 & 4.22 & 5.6 & 1.4 \\
\hline YR_E & $\begin{array}{l}\text { Youghiogheny } \\
\text { River }\end{array}$ & $\begin{array}{c}\text { Downstream of } \\
\text { site YR_D, } \\
100 \text { meters }\end{array}$ & $10 / 06 / 98$ & 1215 & 788 & 17.5 & 10.2 & 138 & 7.7 & 18 & 38 & 16 & 4.23 & 5.6 & 1.4 \\
\hline YR_F & $\begin{array}{l}\text { Youghiogheny } \\
\text { River }\end{array}$ & $\begin{array}{l}\text { at Rt. } 819 \text { Bridge, } \\
\text { Dawson }\end{array}$ & $10 / 06 / 98$ & 1300 & 675 & 19.0 & 10.3 & 180 & 7.2 & 24 & 52 & 20 & 5.18 & 8.0 & 1.3 \\
\hline YR_G & $\begin{array}{l}\text { Youghiogheny } \\
\text { River }\end{array}$ & $\begin{array}{l}\text { at Rt. } 4038 \text { Bridge, } \\
\text { Layton }\end{array}$ & $10 / 06 / 98$ & 1050 & 709 & 16.5 & 8.3 & 186 & 7.4 & 23 & 46 & 18 & 4.69 & 7.1 & 1.4 \\
\hline YR_HA & $\begin{array}{l}\text { Youghiogheny } \\
\text { River }\end{array}$ & $\begin{array}{l}\text { at Rt. } 981 \text { Bridge, } \\
\text { Smithton }\end{array}$ & $10 / 07 / 98$ & 1020 & 702 & 19.0 & 10.5 & 212 & 7.8 & 24 & 45 & 17 & 4.68 & 7.1 & 1.4 \\
\hline YR_HB & $\begin{array}{l}\text { Youghiogheny } \\
\text { River }\end{array}$ & $\begin{array}{c}\text { Downstream of } \\
\text { site YR_HA, } \\
100 \text { meters }\end{array}$ & $10 / 07 / 98$ & 1005 & 672 & 18.5 & 10.1 & 210 & 7.6 & 23 & 45 & 18 & 4.71 & 7.1 & 1.4 \\
\hline YR_I & $\begin{array}{l}\text { Youghiogheny } \\
\text { River }\end{array}$ & $\begin{array}{l}\text { at Rt. } 136 \text { Bridge, } \\
\text { West Newton }\end{array}$ & $10 / 06 / 98$ & 1715 & 688 & 19.5 & 10.1 & 284 & 7.9 & 34 & 59 & 18 & 5.02 & 15 & 1.4 \\
\hline YR_J & $\begin{array}{l}\text { Youghiogheny } \\
\text { River }\end{array}$ & $\begin{array}{l}\text { at USGS } \\
\text { streamflow- } \\
\text { gaging station, } \\
\text { Sutersville }\end{array}$ & $10 / 06 / 98$ & 1405 & 812 & 18.5 & 9.0 & 273 & 7.6 & 31 & 74 & 21 & 5.75 & 21 & 1.6 \\
\hline YR_K & $\begin{array}{l}\text { Youghiogheny } \\
\text { River }\end{array}$ & $\begin{array}{l}\text { at Rt. } 48 \text { Bridge, } \\
\text { Boston }\end{array}$ & $10 / 06 / 98$ & 1605 & 884 & 17.0 & 8.4 & 307 & 7.8 & 33 & 77 & 23 & 6.17 & 22 & 1.8 \\
\hline
\end{tabular}




\begin{tabular}{|c|c|c|c|c|c|c|c|c|c|c|c|c|c|c|c|}
\hline $\begin{array}{c}\text { Site } \\
\text { identifier }\end{array}$ & $\begin{array}{l}\text { Stream } \\
\text { name }\end{array}$ & Location & Date & Time & $\begin{array}{c}\text { Instan- } \\
\text { taneous } \\
\text { streamflow } \\
\left(\mathrm{ft}^{3} / \mathrm{s}\right)\end{array}$ & $\begin{array}{l}\text { Water } \\
\text { temper- } \\
\text { ature } \\
\left({ }^{\circ} \mathrm{C}\right)\end{array}$ & $\begin{array}{c}\text { Dissolved } \\
\text { oxygen } \\
\text { (mg/L) }\end{array}$ & $\begin{array}{c}\text { Specific } \\
\text { conduc- } \\
\text { tance } \\
(\mu \mathrm{S} / \mathrm{cm})\end{array}$ & $\begin{array}{c}\text { Field } \\
\text { pH } \\
\text { (standard } \\
\text { units) }\end{array}$ & $\begin{array}{c}\text { Alkalinity, } \\
\text { total field } \\
(\mathrm{mg} / \mathrm{L} \text { as } \\
\left.\mathrm{CaCO}_{3}\right)\end{array}$ & $\begin{array}{l}\text { Sulfate } \\
(\mathrm{mg} / \mathrm{L})\end{array}$ & $\begin{array}{c}\text { Calcium } \\
\text { (mg/L) }\end{array}$ & $\begin{array}{l}\text { Magne- } \\
\text { sium } \\
(\mathrm{mg} / \mathrm{L})\end{array}$ & $\begin{array}{c}\text { Sodium } \\
(\mathrm{mg} / \mathrm{L})\end{array}$ & $\begin{array}{c}\text { Potas- } \\
\text { sium } \\
(\mathrm{mg} / \mathrm{L})\end{array}$ \\
\hline \multicolumn{16}{|c|}{ Tributary sites } \\
\hline TR_1 & Indian Creek & near mouth & $10 / 05 / 98$ & 1515 & 23.4 & 16.5 & 10.5 & 270 & 7.3 & 21 & 88 & 32 & 8.48 & 10 & 1.9 \\
\hline TR_2 & Laurel Run & near mouth & $10 / 06 / 98$ & 0925 & .028 & 13.5 & 9.5 & 306 & 7.9 & 110 & 18 & 41 & 8.07 & 7.5 & 1.5 \\
\hline TR_3 & Dunbar Creek & near mouth & $10 / 05 / 98$ & 1225 & 4.31 & 14.0 & 11.1 & 213 & 8.4 & 45 & 55 & 32 & 5.34 & 8.2 & 2.0 \\
\hline TR_4 & Connell Run & near mouth & $10 / 06 / 98$ & 1000 & .342 & 15.0 & 9.5 & 384 & 8.2 & 120 & 46 & 57 & 6.33 & 18 & 2.7 \\
\hline TR_5 & Opossum Run & near mouth & $10 / 05 / 98$ & 1350 & 1.01 & 15.0 & 10.3 & 419 & 8.4 & 140 & 75 & 57 & 12.3 & 25 & 3.7 \\
\hline TR_6 & Mounts Creek & near mouth & $10 / 05 / 98$ & 1300 & 2.77 & 15.0 & 11.9 & 376 & 8.0 & 81 & 67 & 45 & 8.47 & 14 & 3.3 \\
\hline TR_7 & Galley Run & near mouth & $10 / 06 / 98$ & 1050 & .768 & 14.0 & 6.3 & 952 & 5.8 & 26 & 430 & 110 & 36.0 & 6.3 & 1.9 \\
\hline TR_8 & Hickman Run & near mouth & $10 / 05 / 98$ & 1600 & .153 & 16.0 & 8.9 & 844 & 7.1 & 22 & 500 & 150 & 39.0 & 10 & 3.3 \\
\hline TR_9 & Dickerson Run & near mouth & $10 / 06 / 98$ & 1235 & .391 & 18.5 & 7.2 & 668 & 8.0 & 110 & 210 & 94 & 18.0 & 23 & 7.9 \\
\hline TR_10 & Smiley Run & near mouth & $10 / 05 / 98$ & 1630 & .319 & 18.0 & 8.4 & 332 & 8.1 & 120 & 32 & 48 & 9.17 & 12 & 5.6 \\
\hline TR_11 & Laurel Run & near mouth & $10 / 05 / 98$ & 1700 & .124 & 14.5 & 8.8 & 361 & 7.9 & 90 & 82 & 49 & 13.4 & 13 & 3.8 \\
\hline TR_12A & Furnace Run & near mouth & $10 / 05 / 98$ & 1630 & .074 & 15.0 & 10.1 & 289 & 7.8 & 110 & 27 & 36 & 6.84 & 7.7 & 2.6 \\
\hline TR_12B & & near mouth & $10 / 06 / 98$ & 0945 & .074 & 14.0 & 7.5 & 721 & 7.9 & 73 & 46 & 74 & 17.3 & 63 & 3.5 \\
\hline TR_13 & Virgin Run & near mouth & $10 / 06 / 98$ & 1030 & .068 & 14.5 & 8.4 & 182 & 7.8 & 72 & 12 & 25 & 5.82 & 6.8 & 2.6 \\
\hline TR_14 & Washington Run & near mouth & $10 / 06 / 98$ & 1340 & .836 & 16.5 & 10.0 & 428 & 8.1 & 92 & 74 & 54 & 11.9 & 23 & 3.4 \\
\hline TR_15 & Browneller Run & near mouth & $10 / 06 / 98$ & 1215 & .04 & 16.5 & 7.2 & 693 & 7.8 & 240 & 83 & 73 & 22.0 & 33 & 3.2 \\
\hline TR_16 & Jacobs Creek & near mouth & $10 / 06 / 98$ & 1100 & 13.2 & 15.0 & 10.7 & 416 & 8.1 & 66 & 97 & 41 & 11.3 & 18 & 4.1 \\
\hline TR_17 & Cedar Creek & near mouth & $10 / 06 / 98$ & 1700 & .70 & 17.0 & 9.0 & 1,100 & 7.9 & 270 & 190 & 70 & 19.5 & 130 & 3.9 \\
\hline TR_18 & Sewickley Creek & near mouth & $10 / 06 / 98$ & 1545 & 51.9 & 17.5 & 11.7 & 1,000 & 7.3 & 100 & 350 & 92 & 22.7 & 110 & 5.4 \\
\hline TR_19 & Pollock Run & near mouth & $10 / 06 / 98$ & 1355 & .356 & 16.5 & 8.3 & 326 & 8.1 & 150 & 210 & 87 & 29.0 & 28 & 2.9 \\
\hline TR_20 & Gillespie Run & near mouth & $10 / 07 / 98$ & 0935 & 2.87 & 13.5 & 9.1 & 1,210 & 7.3 & 240 & 390 & 80 & 27.2 & 180 & 2.7 \\
\hline TR_21 & Crawford Run & near mouth & $\begin{array}{c}\text { Not } \\
\text { sampled- } \\
\text { dry }\end{array}$ & & 0 & & & & & & & & & & \\
\hline TR_22 & Long Run & near mouth & $10 / 06 / 98$ & 1550 & 1.94 & 17.0 & 8.3 & 708 & 7.9 & 120 & 150 & 79 & 16.4 & 54 & 3.5 \\
\hline
\end{tabular}




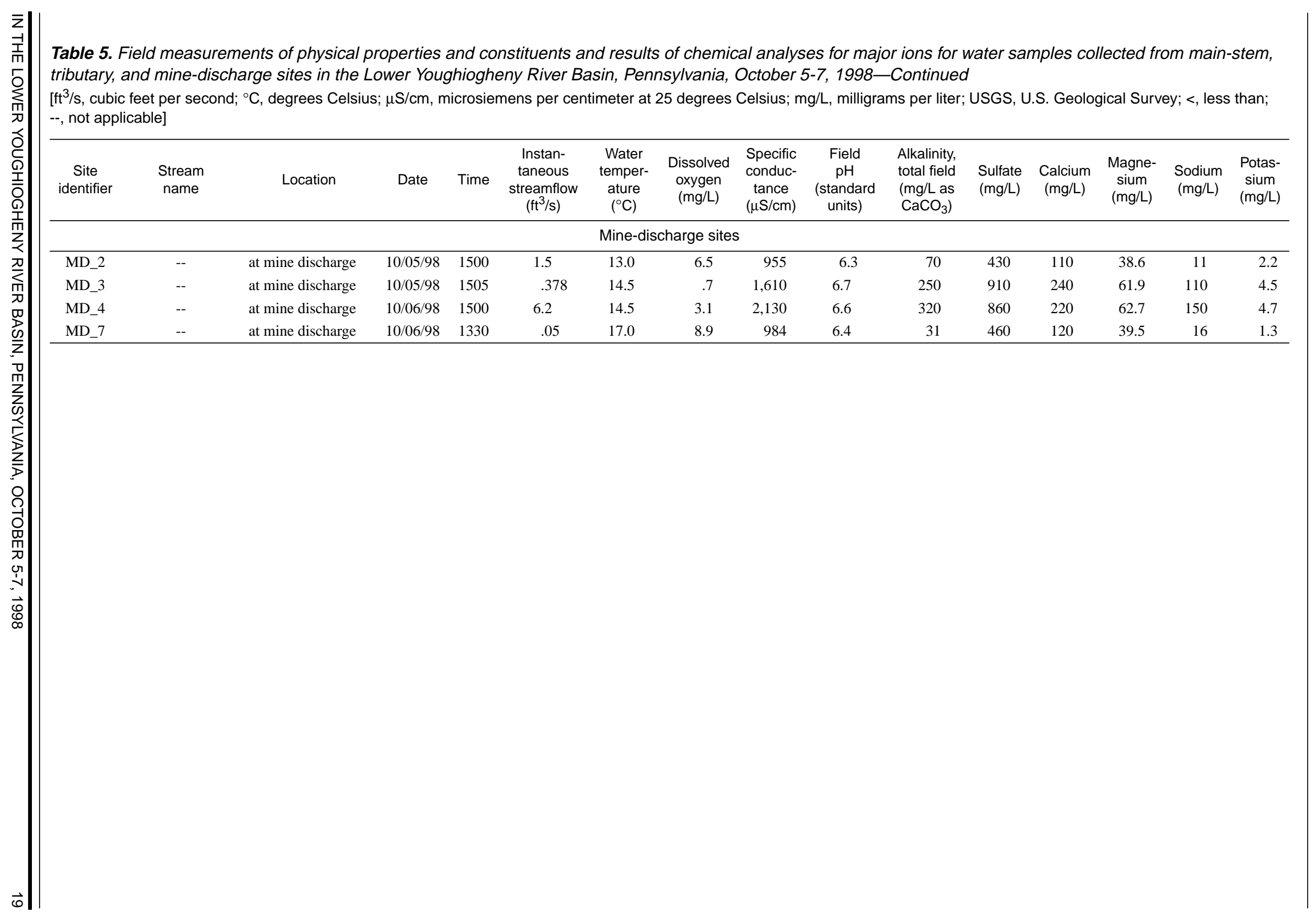




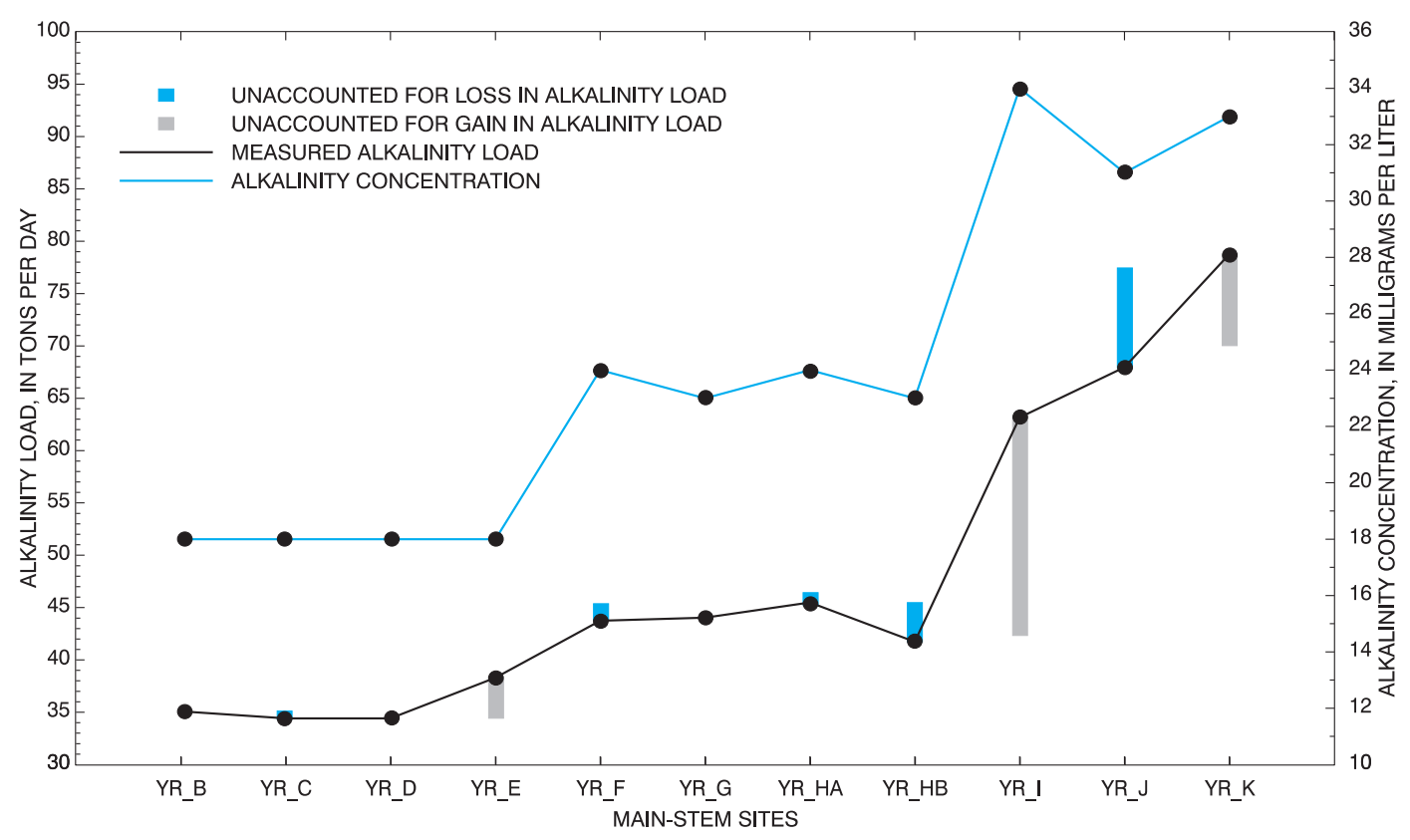

Figure 9. Measured alkalinity loads and concentrations at main-stem sites during the synoptic survey in the Lower Youghiogheny River Basin, Pennsylvania, October 5-7, 1998. (Unaccounted for losses and gains are the result of subtracting the calculated alkalinity load-the sum of the measured alkalinity load at the closest upstream main-stem site plus the loads measured for any tributaries flowing into the Youghiogheny River between the two sites-from the measured load at each site.)

The net effect is that 2 moles of alkalinity $\left(\mathrm{HCO}_{3}{ }^{-}\right)$are lost for each mole of ferrous iron $\left(\mathrm{Fe}^{2+}\right)$ that is oxidized. Water-chemistry data from Sewickley Creek (TR_18) and from the Youghiogheny River at Sutersville (Site YR_J) support this reasoning. For example, the concentration of dissolved iron (most of which is likely to be ferrous iron) entering the Youghiogheny River from Sewickley Creek is $0.13 \mathrm{mg} / \mathrm{L}$ (table 6 ). This value is more than two times the concentration of dissolved iron in the Youghiogheny River at Sutersville ( $0.05 \mathrm{mg} / \mathrm{L})$. Apparently, the ferrous iron contributed from Sewickley Creek is oxidized to ferric iron by the time it reaches Sutersville. The total iron data lend additional evidence for this. There is nearly a three-fold increase in the concentration of total iron at sampling site YR_J $(0.32 \mathrm{mg} / \mathrm{L})$ relative to site YR_I $(0.12 \mathrm{mg} / \mathrm{L})$. The implication is that, once in the Youghiogheny River, ferrous iron from Sewickley Creek is oxidized to ferric iron with an accompanying loss of alkalinity defined by equation 1 . This oxidation is believed to account for part of the loss of alkalinity between site YR_I and site YR_J.

Approximately one-third of the load of total alkalinity in the Youghiogheny River at McKeesport is attributed to Sewickley Creek, which contributes 14 ton/d. A number of small inputs between sites YR_D and YR_F contribute another 7.0 ton/d, the largest coming from MD_4 (5.4 ton/d). A large unknown source between sites YR_J and YR_K contributes another 9 ton/d. The relative importance of each of the water sources to the alkalinity load of the Youghiogheny River is shown in figure 10. 


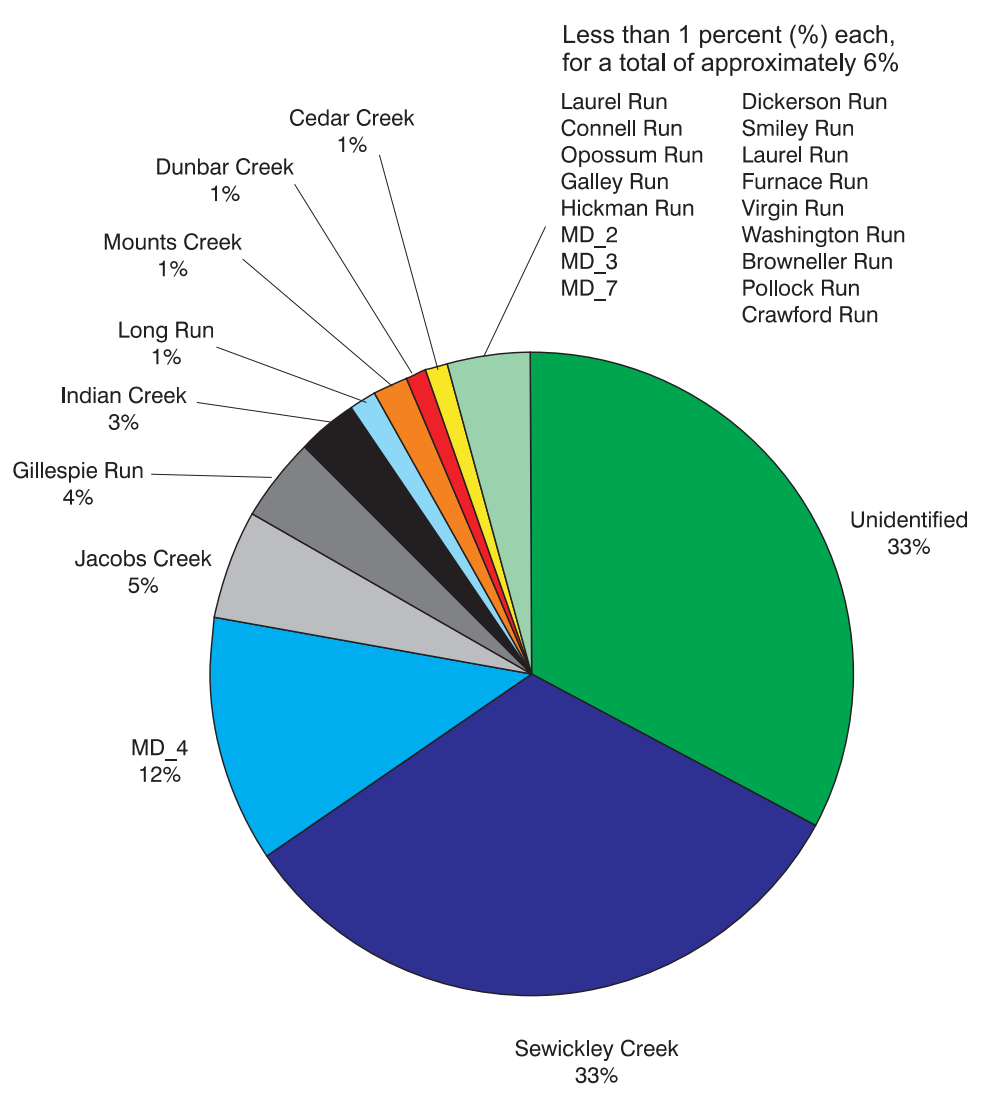

Figure 10. Sources of alkalinity load (43 tons per day) between the Lower Youghiogheny River upstream from Indian Creek (site YR_A) and McKeesport (site YR_K) during the synoptic survey in the Lower Youghiogheny River Basin, Pennsylvania, October 5-7, 1998.

Run and Gillespie Run), and three of the four mine-discharge sites (MD_2, MD_3, and MD_4) during the Lower Youghiogheny River survey. On the basis of these measurements, toxic conditions appear to exist at several locations in the Youghiogheny River and its tributaries.

At one sarmpling location (Laurel Run), the concentration of dissolved ferrous iron $\left(\mathrm{Fe}^{2+}\right)$ was higher than the concentration of total iron (table 6). Of course, this result is impossible and indicates a probable error in the laboratory analyses. At the other sites, measured concentrations of dissolved iron were lower than total iron. In most samples (35 of 38 sites), concentrations of dissolved oxygen were higher than $7.0 \mathrm{mg} / \mathrm{L}$. These concentrations of dissolved oxygen provide sufficient oxygen to oxidize the soluble ferrous iron to the insoluble ferric hydroxide. In general, elevated dissolved-iron concentrations correlate with low dissolved-oxygen concentrations.

\section{Sulfate}

Because iron is removed from the water when mine discharges are

\section{Iron}

The most obvious sign of mine drainage in the study area is the rust-orange sludge that covers the beds of affected streams. The iron oxide precipitate affects aquatic life and reduces the aesthetic and recreational appeal of the stream. Many tributaries and seepages flowing into the Youghiogheny River show evidence of this iron staining. During the survey, concentrations of total iron in water exceeded Pennsylvania's water-quality standard of $1.5 \mathrm{mg} / \mathrm{L}$ (Pennsylvania Department of Environmental Protection, 1998) at two main-stem sites (YR_A and YR_C), four tributary sites (Galley Run, Hickman Run, Sewickley Creek, and Gillespie Run), and three mine-discharge sites (MD_2, MD_3, and MD_4) (table 6). Pennsylvania's water-quality standard for dissolved iron is $0.3 \mathrm{mg} / \mathrm{L}$ (Pennsylvania Department of Environmental Protection, 1998). This concentration was exceeded at one main-stem site (YR_C), two tributary sites (Galley treated and because iron is chemically reactive and precipitates as $\mathrm{Fe}(\mathrm{OH})_{3}$, sulfate is a better indicator of the total mine drainage entering the Youghiogheny River than iron. However, untreated and remediated mine discharges cannot be distinguished using sulfate as an indicator because neither the natural nor the engineered processes that remove iron will remove sulfate. Also, sulfate is not always conserved in natural processes; sulfate is both formed by the oxidation of sulfide and destroyed by biotic sulfate reduction. Thus, the analysis based on sulfate cannot be considered strictly quantitative.

The sulfate concentration in water at the upstream-most study site (YR_A) was $33 \mathrm{mg} / \mathrm{L}$, or about 15 times the concentration in atmospheric deposition falling in southwestern Pennsylvania (National Atmospheric Deposition Program, 2000). Thus, at the upstream limit of the study area, the Youghiogheny River already has received inputs of sulfate well above background concentrations. The Casselman River, which flows into the Youghiogheny River upstream of the study area at Confluence, is the likely source of 
much of the elevated sulfate concentration. The Casselman River Basin contains many active and historical mining sites and has a sulfate yield of 98 tons of sulfate per square mile of drainage area (Sams and Beer, 2000). Within the study area, sulfate concentrations in the Youghiogheny River steadily increase from upstream to downstream (fig. 11, table 5). A sulfate concentration of $77 \mathrm{mg} / \mathrm{L}$ was measured at the downstream-most sampling site (YR_K). Measured concentrations of sulfate exceeded Pennsylvania's waterquality standard of $250 \mathrm{mg} / \mathrm{L}$ at four tributary sites (Galley Run, Hickman Run, Sewickley Creek, and Gillespie Run) and at all four mine-discharge sites but not at any of the main-stem sites.

The samples from the Lower Youghiogheny River Basin showed large increases in the measured sulfate load between sites YR_D and YR_F and between sites YR_HB and YR_K (fig. 11). The elevation in sulfate concentration between sites YR_E (38 mg/L) and YR_F (52 mg/L) corresponds to major iron inputs in this stream reach. The increase in sulfate load can be attributed to mine discharge MD_4, with an elevated sulfate concentration ( $860 \mathrm{mg} / \mathrm{L})$ and a high flow $\left(6.2 \mathrm{ft}^{3} / \mathrm{s}\right)$. The large increase between sites YR_I (110 ton/d) and YR_J (162 ton/d) can be attributed almost entirely to the contribution from Sewickley Creek (49 ton/d). However, the increase between sites YR_HB (82 ton/d) and YR_I (110 ton/d) cannot be explained by the small input measured for Cedar Creek (0.36 ton/d). Similarly, the increase in measured sulfate load at site YR_K (184 ton/d) cannot be explained by tributary inputs. For these reaches, the unaccounted for gain in measured sulfate load must be attributed to unidentified sources. This result parallels the unidentified loads of alkalinity at these sites and mirrors the unidentified increase in flow for these sites. All these indicators point to some source of mine water entering the river that is not coming from tributaries. Approximately 25 percent of the measured sulfate load contributed between Connellsville and McKeesport is unaccounted for (fig. 12). These unaccounted for gains are believed to be from seeps to the streambed from underground mine pools. The relative contribution of each of the sulfate sources in the Lower Youghiogheny River Basin is shown in figure 12.

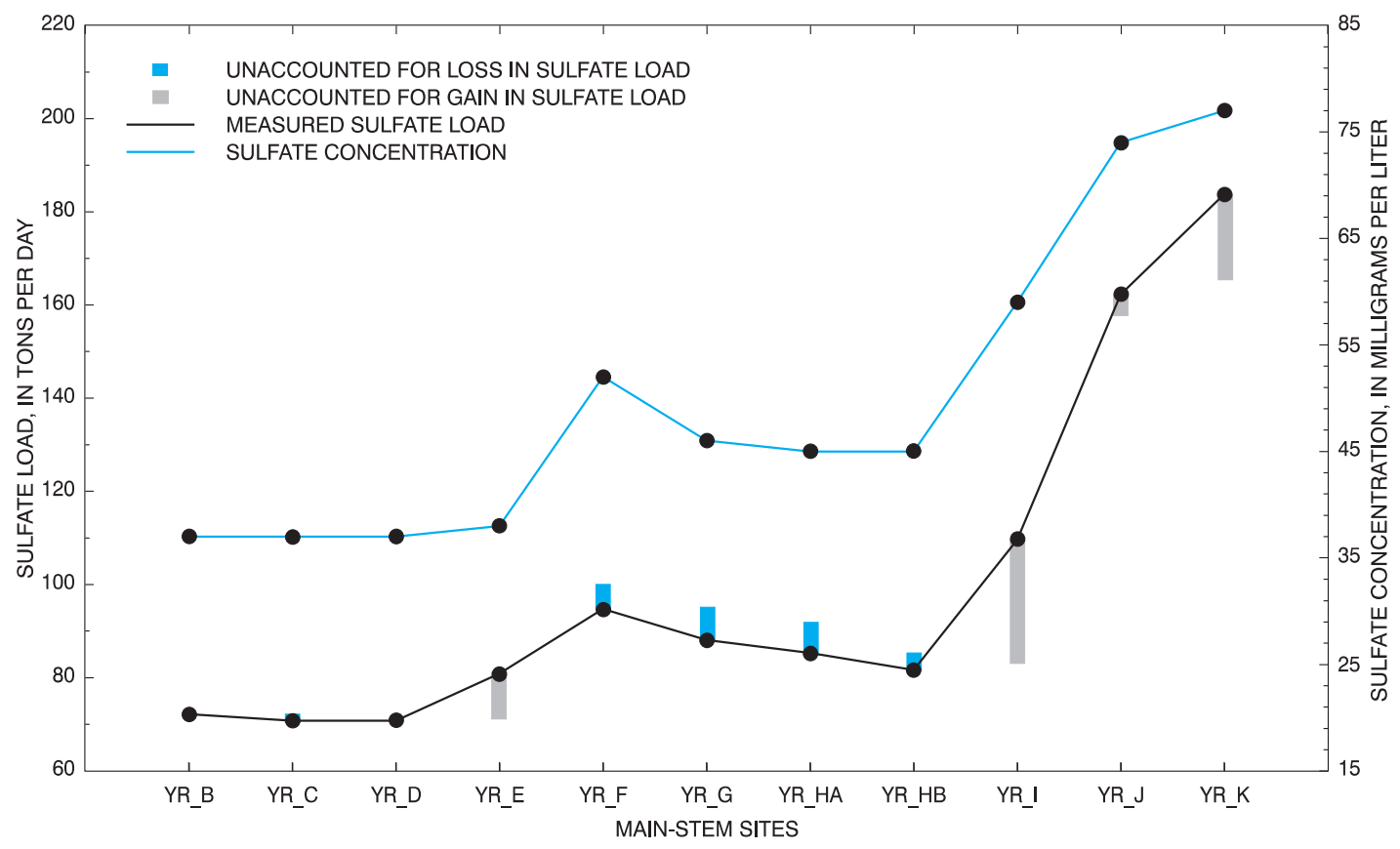

Figure 11. Measured sulfate loads and concentrations at main-stem sites during the synoptic survey in the Lower Youghiogheny River Basin, Pennsylvania, October 5-7, 1998. (Unaccounted for losses and gains are the result of subtracting the calculated sulfate load-the sum of the measured sulfate load at the closest upstream main-stem site plus the loads measured for any tributaries flowing into the Youghiogheny River between the two sites-from the measured load at each site.) 


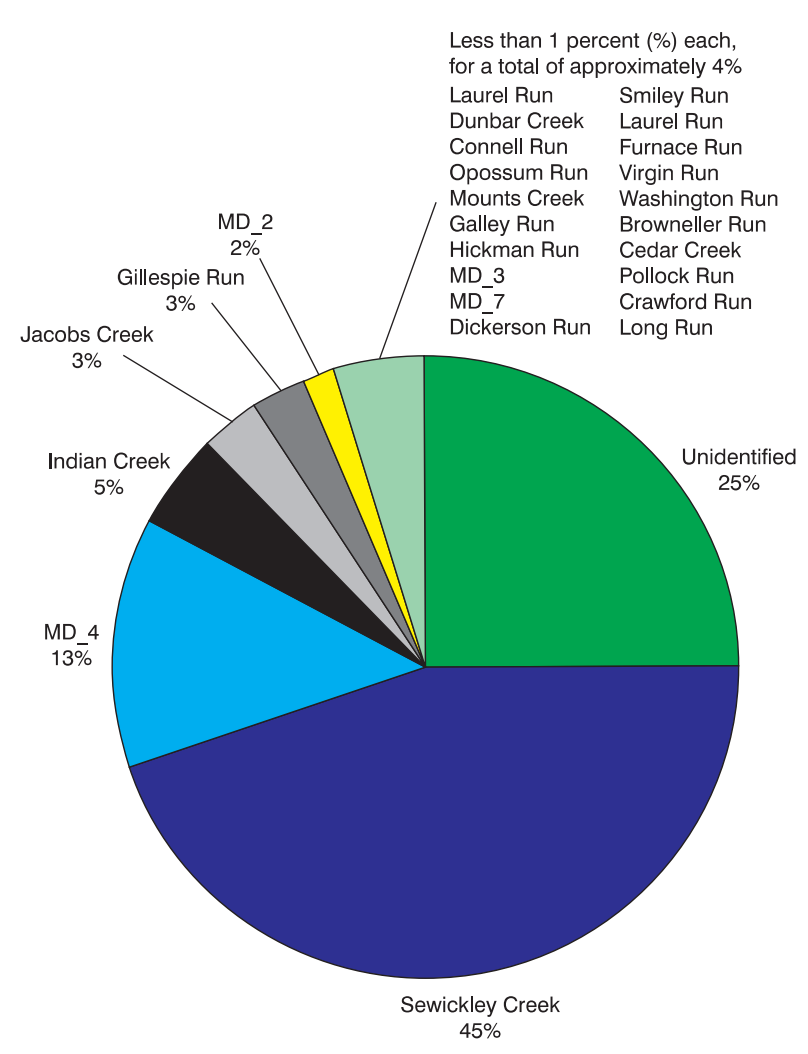

Figure 12. Sources of sulfate load (110 tons per day) between the Lower Youghiogheny River upstream from Indian Creek (site YR_A) and McKeesport (site YR_K) during the synoptic survey in the Lower Youghiogheny River Basin, Pennsylvania, October 5-7, 1998.

\section{Metals}

$\mathrm{As}, \mathrm{Cd}, \mathrm{Pd}, \mathrm{Sb}$, and Se were less than the reporting limit in all the samples, and the concentrations of $\mathrm{Ba}$, $\mathrm{Be}, \mathrm{Co}, \mathrm{Cu}$, and $\mathrm{Zn}$ did not exceed $0.2 \mathrm{mg} / \mathrm{L}$ in any sample (table 6). Aluminum was measurable in all the samples except one. The highest concentration of total aluminum for a tributary was in Galley Run $(1.31 \mathrm{mg} / \mathrm{L})$. Mine discharge MD_7 had the highest concentration of total aluminum of any site $(3.76 \mathrm{mg} / \mathrm{L})$. The toxicity of aluminum is a function of the amount of dissolved aluminum in water and the $\mathrm{pH}$ of that water (Smith and Haines, 1995). Generally, concentrations of dissolved aluminum larger than $0.2 \mathrm{mg} / \mathrm{L}(200 \mu \mathrm{g} / \mathrm{L})$ are toxic at $\mathrm{pH}$ levels less than $5.0 \mathrm{pH}$ units (Smith and Haines, 1995). Dissolved aluminum concentrations in the Youghiogheny River and its tributaries were less than $0.2 \mathrm{mg} / \mathrm{L}$ at all sampling sites except for site TR_7 (Galley Run). At this site, a dissolved aluminum concentration of $0.77 \mathrm{mg} / \mathrm{L}$ was measured. Aluminum toxicity is likely at this site. Acidic mine drainage can leach aluminum from rocks and minerals. If the mine drainage is neutralized by alkaline water, the higher $\mathrm{pH}$ can cause the aluminum to precipitate. The aluminum precipitate commonly stays suspended in the water column.

\section{Other lons}

A consideration of measured and calculated loads for all the major ions as a group may lead to a better understanding of the water-quality effects in the Lower Youghiogheny River. For this analysis, all constituent loads were converted to a load in moles per day. Using moles as the unit of measurement allows comparisons of different ions to be made on a one-to-one basis. There is reasonably good agreement between measured loads and calculated loads at sites YR_C and YR_D (fig. 13). At site YR_E, the measured loads are larger than calculated loads. This site is only about $300 \mathrm{ft}$ downstream from site YR_D and there are no known inputs between the two sites. The difference between measured and calculated loads can be attributed to the increased streamflow measured at site YR_E $\left(788 \mathrm{ft}^{3} / \mathrm{s}\right)$, compared with streamflow at site YR_D $\left(708 \mathrm{ft}^{3} / \mathrm{s}\right)$.

The reach of the Lower Youghiogheny River from sampling site YR_E through YR_HB has a relatively steady flow. Throughout this reach, measured ion loads are less than calculated loads, by small amounts (fig. 13). These small differences or unaccounted for losses likely are caused by measurement error. However, the stream could be losing water to underground mine workings in this reach. If so, the losses are small and probably do not represent priority stream sections for remediation. The Pittsburgh Coal seam underlies the upstream section of this reach (fig. 3), so losing water to this formation is possible.

Large differences between measured and calculated ion loads occur downstream from site YR_HB. Between sites YR_HB and YR_I, measured loads of sodium, alkalinity, and sulfate are dramatically larger than calculated loads. The implication is that the unaccounted for gains in these constituents are entering the Lower Youghiogheny River from some source other than the tributaries measured in this survey. The likely source is from abandoned underground coal mines, providing water directly to the Youghiogheny River. This hypothesis seems likely because the Pittsburgh coal seam is present at site YR_HB and continues downstream throughout the remainder of the study area. 


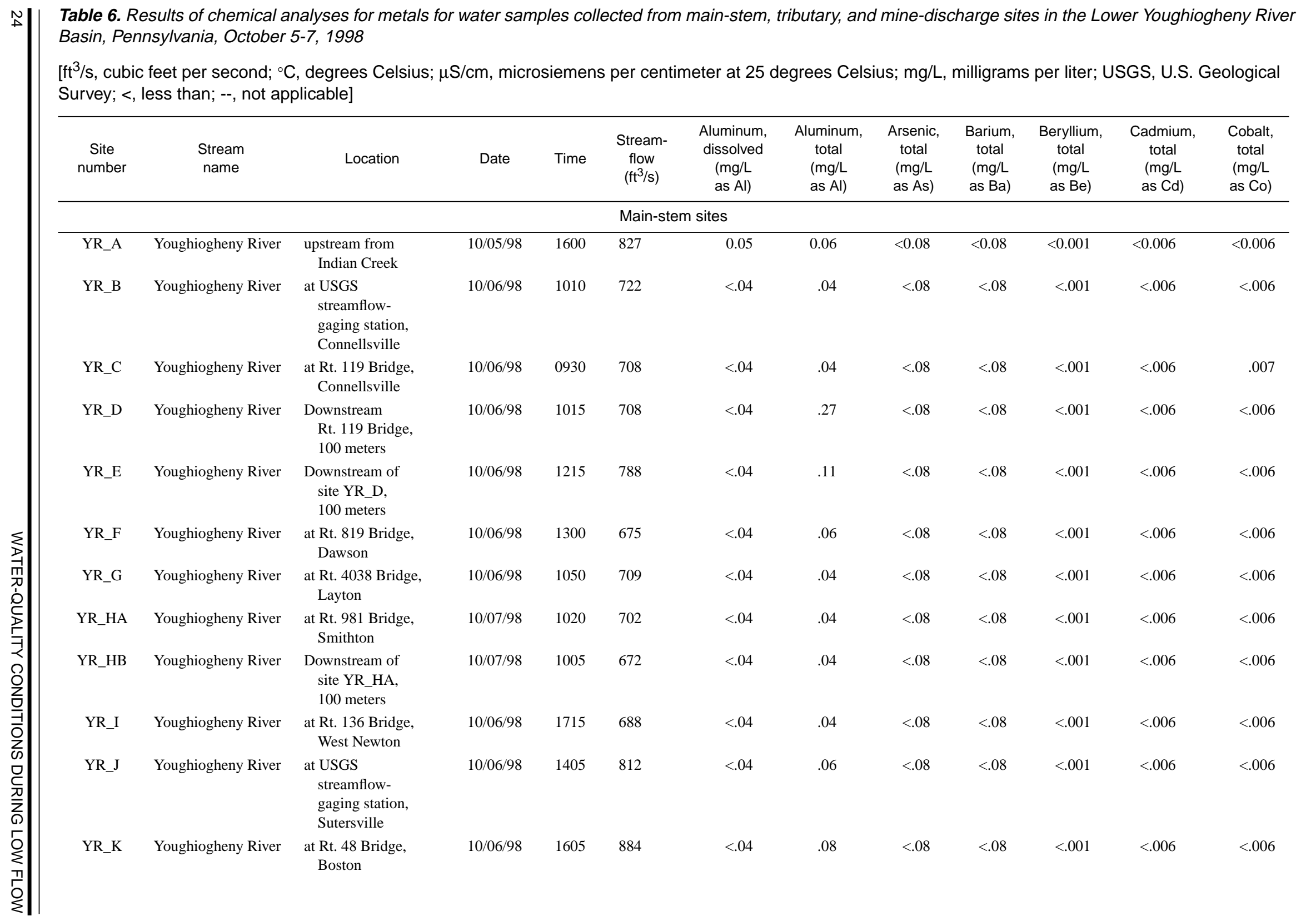




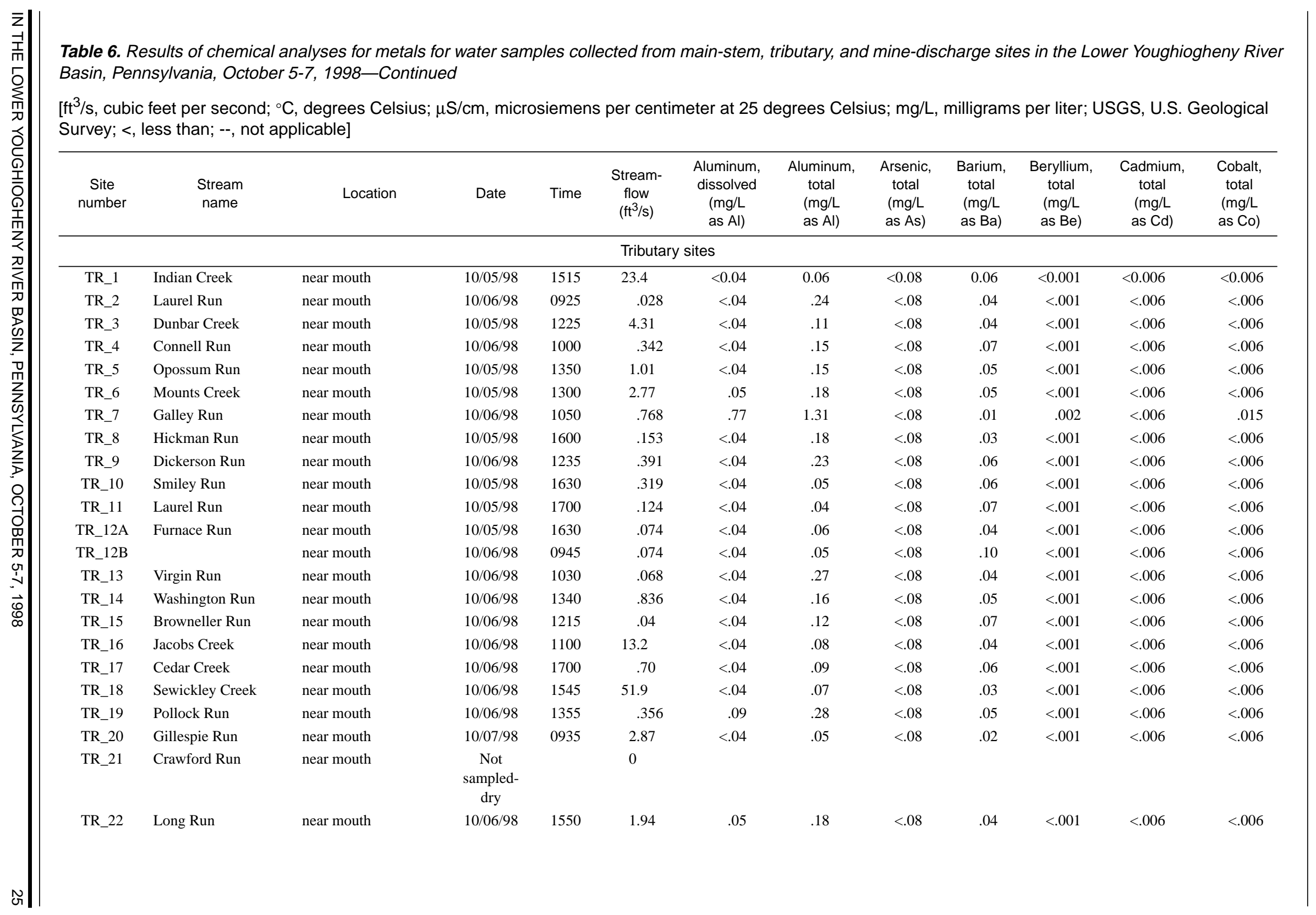


이 Table 6. Results of chemical analyses for metals for water samples collected from main-stem, tributary, and mine-discharge sites in the Lower Youghiogheny River Basin, Pennsylvania, October 5-7, 1998-Continued

$\left[\mathrm{ft}^{3} / \mathrm{s}\right.$, cubic feet per second; ${ }^{\circ} \mathrm{C}$, degrees Celsius; $\mu \mathrm{S} / \mathrm{cm}$, microsiemens per centimeter at 25 degrees Celsius; mg/L, milligrams per liter; USGS, U.S. Geological Survey; <, less than; --, not applicable]

\begin{tabular}{|c|c|c|c|c|c|c|c|c|c|c|c|c|}
\hline $\begin{array}{c}\text { Site } \\
\text { number }\end{array}$ & $\begin{array}{c}\text { Stream } \\
\text { name }\end{array}$ & Location & Date & Time & $\begin{array}{l}\text { Stream- } \\
\text { flow } \\
\left(\mathrm{ft}^{3} / \mathrm{s}\right)\end{array}$ & $\begin{array}{l}\text { Aluminum, } \\
\text { dissolved } \\
\text { (mg/L } \\
\text { as } \mathrm{Al})\end{array}$ & $\begin{array}{c}\text { Aluminum, } \\
\text { total } \\
(\mathrm{mg} / \mathrm{L} \\
\text { as } \mathrm{Al})\end{array}$ & $\begin{array}{c}\text { Arsenic, } \\
\text { total } \\
(\mathrm{mg} / \mathrm{L} \\
\text { as As) }\end{array}$ & $\begin{array}{c}\text { Barium, } \\
\text { total } \\
(\mathrm{mg} / \mathrm{L} \\
\text { as Ba) }\end{array}$ & $\begin{array}{c}\text { Beryllium, } \\
\text { total } \\
(\mathrm{mg} / \mathrm{L} \\
\text { as } \mathrm{Be})\end{array}$ & $\begin{array}{c}\text { Cadmium, } \\
\text { total } \\
(\mathrm{mg} / \mathrm{L} \\
\text { as Cd })\end{array}$ & $\begin{array}{c}\text { Cobalt, } \\
\text { total } \\
\text { (mg/L } \\
\text { as Co) }\end{array}$ \\
\hline \multicolumn{13}{|c|}{ Mine-discharge sites } \\
\hline MD_2 & -- & at mine discharge & $10 / 05 / 98$ & 1500 & 1.5 & 0.11 & 0.20 & $<0.08$ & 0.01 & $<0.001$ & $<0.006$ & 0.010 \\
\hline MD_3 & -- & at mine discharge & $10 / 05 / 98$ & 1505 & .378 & $<.04$ & .07 & $<.08$ & .01 & $<.001$ & $<.006$ & $<.006$ \\
\hline MD_4 & -- & at mine discharge & $10 / 06 / 98$ & 1500 & 6.2 & $<.04$ & $<.04$ & $<.08$ & .01 & $<.001$ & $<.006$ & $<.006$ \\
\hline MD_7 & -- & at mine discharge & $10 / 06 / 98$ & 1330 & .05 & .16 & 3.76 & $<.08$ & .02 & .001 & $<.006$ & .023 \\
\hline
\end{tabular}




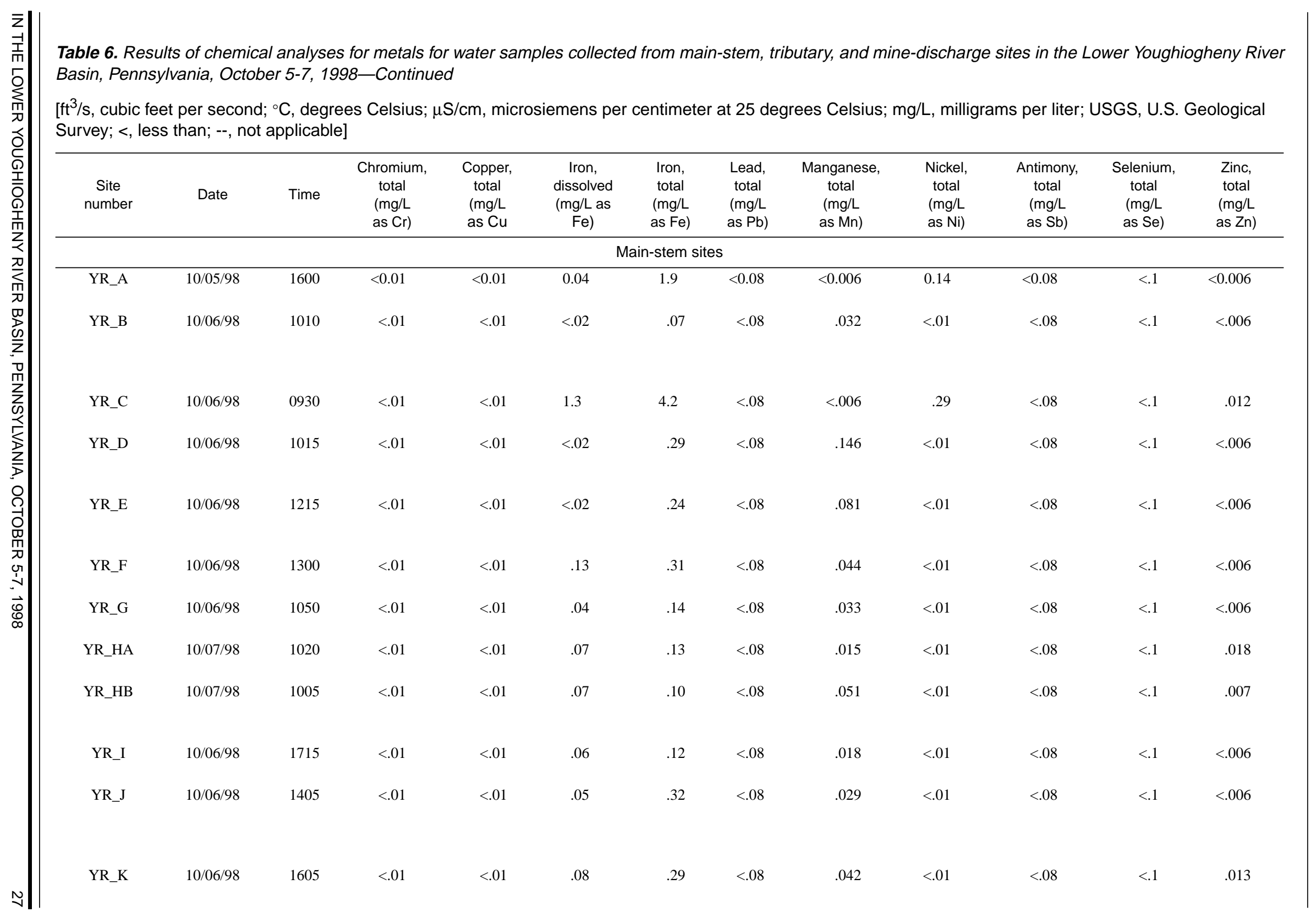




\begin{tabular}{|c|c|c|c|c|c|c|c|c|c|c|c|c|}
\hline $\begin{array}{c}\text { Site } \\
\text { number }\end{array}$ & Date & Time & $\begin{array}{c}\text { Chromium, } \\
\text { total } \\
(\mathrm{mg} / \mathrm{L} \\
\text { as } \mathrm{Cr})\end{array}$ & $\begin{array}{c}\text { Copper, } \\
\text { total } \\
(\mathrm{mg} / \mathrm{L} \\
\text { as Cu }\end{array}$ & $\begin{array}{c}\text { Iron, } \\
\text { dissolved } \\
(\mathrm{mg} / \mathrm{L} \text { as } \\
\mathrm{Fe})\end{array}$ & $\begin{array}{c}\text { Iron, } \\
\text { total } \\
\text { (mg/L } \\
\text { as Fe) }\end{array}$ & $\begin{array}{c}\text { Lead, } \\
\text { total } \\
\text { (mg/L } \\
\text { as } \mathrm{Pb})\end{array}$ & $\begin{array}{c}\text { Manganese, } \\
\text { total } \\
(\mathrm{mg} / \mathrm{L} \\
\text { as } \mathrm{Mn})\end{array}$ & $\begin{array}{c}\text { Nickel, } \\
\text { total } \\
(\mathrm{mg} / \mathrm{L} \\
\text { as Ni) }\end{array}$ & $\begin{array}{c}\text { Antimony, } \\
\text { total } \\
\text { (mg/L } \\
\text { as } \mathrm{Sb})\end{array}$ & $\begin{array}{c}\text { Selenium, } \\
\text { total } \\
(\mathrm{mg} / \mathrm{L} \\
\text { as } \mathrm{Se})\end{array}$ & $\begin{array}{c}\text { Zinc, } \\
\text { total } \\
\text { (mg/L } \\
\text { as Zn) }\end{array}$ \\
\hline \multicolumn{13}{|c|}{ Tributary sites } \\
\hline TR_1 & $10 / 05 / 98$ & 1515 & 0.47 & $<0.01$ & $<0.02$ & 0.14 & $<0.08$ & $<0.006$ & $<0.01$ & $<0.08$ & $<0.1$ & 0.013 \\
\hline TR_2 & $10 / 06 / 98$ & 0925 & $<.01$ & $<.01$ & .04 & .28 & $<.08$ & .045 & $<.01$ & $<.08$ & $<.1$ & .006 \\
\hline TR_3 & $10 / 05 / 98$ & 1225 & .03 & $<.01$ & .04 & .15 & $<.08$ & .022 & .02 & $<.08$ & $<.1$ & .007 \\
\hline TR_4 & $10 / 06 / 98$ & 1000 & $<.01$ & $<.01$ & $<.02$ & .20 & $<.08$ & .026 & $<.01$ & $<.08$ & $<.1$ & $<.006$ \\
\hline TR_5 & $10 / 05 / 98$ & 1350 & $<.01$ & $<.01$ & .05 & .83 & $<.08$ & .193 & $<.01$ & $<.08$ & $<.1$ & .008 \\
\hline TR_6 & $10 / 05 / 98$ & 1300 & $<.01$ & $<.01$ & .07 & .38 & $<.08$ & .040 & $<.01$ & $<.08$ & $<.1$ & .009 \\
\hline TR_7 & $10 / 06 / 98$ & 1050 & $<.01$ & $<.01$ & 16 & 18 & $<.08$ & .647 & .04 & $<.08$ & $<.1$ & .056 \\
\hline TR_8 & $10 / 05 / 98$ & 1600 & $<.01$ & $<.01$ & .08 & 1.8 & $<.08$ & .348 & .03 & $<.08$ & $<.1$ & .021 \\
\hline TR_9 & $10 / 06 / 98$ & 1235 & $<.01$ & $<.01$ & $<.02$ & .26 & $<.08$ & .055 & $<.01$ & $<.08$ & $<.1$ & .006 \\
\hline TR_10 & $10 / 05 / 98$ & 1630 & $<.01$ & $<.01$ & $<.02$ & .08 & $<.08$ & .047 & $<.01$ & $<.08$ & $<.1$ & $<.006$ \\
\hline TR_11 & $10 / 05 / 98$ & 1700 & .79 & .01 & .27 & $<.02$ & $<.08$ & $<.006$ & $<.01$ & $<.08$ & $<.1$ & $<.006$ \\
\hline TR_12A & $10 / 05 / 98$ & 1630 & $<.01$ & $<.01$ & .04 & .14 & $<.08$ & $<.006$ & $<.01$ & $<.08$ & $<.1$ & $<.006$ \\
\hline TR_12B & $10 / 06 / 98$ & 0945 & $<.01$ & $<.01$ & $<.02$ & .11 & $<.08$ & .013 & $<.01$ & $<.08$ & $<.1$ & .014 \\
\hline TR_13 & $10 / 06 / 98$ & 1030 & $<.01$ & $<.01$ & $<.02$ & .24 & $<.08$ & .023 & $<.01$ & $<.08$ & $<.1$ & .013 \\
\hline TR_14 & $10 / 06 / 98$ & 1340 & $<.01$ & $<.01$ & $<.02$ & .15 & $<.08$ & .031 & $<.01$ & $<.08$ & $<.1$ & $<.006$ \\
\hline TR_15 & $10 / 06 / 98$ & 1215 & $<.01$ & $<.01$ & $<.02$ & .12 & $<.08$ & .035 & $<.01$ & $<.08$ & $<.1$ & .015 \\
\hline TR_16 & $10 / 06 / 98$ & 1100 & $<.01$ & $<.01$ & $<.02$ & .11 & $<.08$ & .010 & $<.01$ & $<.08$ & $<.1$ & .006 \\
\hline TR_17 & $10 / 06 / 98$ & 1700 & $<.01$ & $<.01$ & .05 & .29 & $<.08$ & .144 & $<.01$ & $<.08$ & $<.1$ & $<.006$ \\
\hline TR_18 & $10 / 06 / 98$ & 1545 & $<.01$ & $<.01$ & .13 & 2.4 & $<.08$ & .165 & $<.01$ & $<.08$ & $<.1$ & $<.006$ \\
\hline TR_19 & $10 / 06 / 98$ & 1355 & $<.01$ & $<.01$ & $<.02$ & .17 & $<.08$ & .196 & .02 & $<.08$ & $<.1$ & .007 \\
\hline TR_20 & $10 / 07 / 98$ & 0935 & $<.01$ & $<.01$ & 5.7 & 14 & $<.08$ & .398 & .01 & $<.08$ & $<.1$ & .009 \\
\hline TR_21 & $\begin{array}{c}\text { Not } \\
\text { sampled- } \\
\text { dry }\end{array}$ & & & & & & & & & & & \\
\hline TR_22 & $10 / 06 / 98$ & 1550 & $<.01$ & $<.01$ & $<.02$ & .16 & $<.08$ & .186 & $<.01$ & $<.08$ & $<.1$ & .013 \\
\hline
\end{tabular}




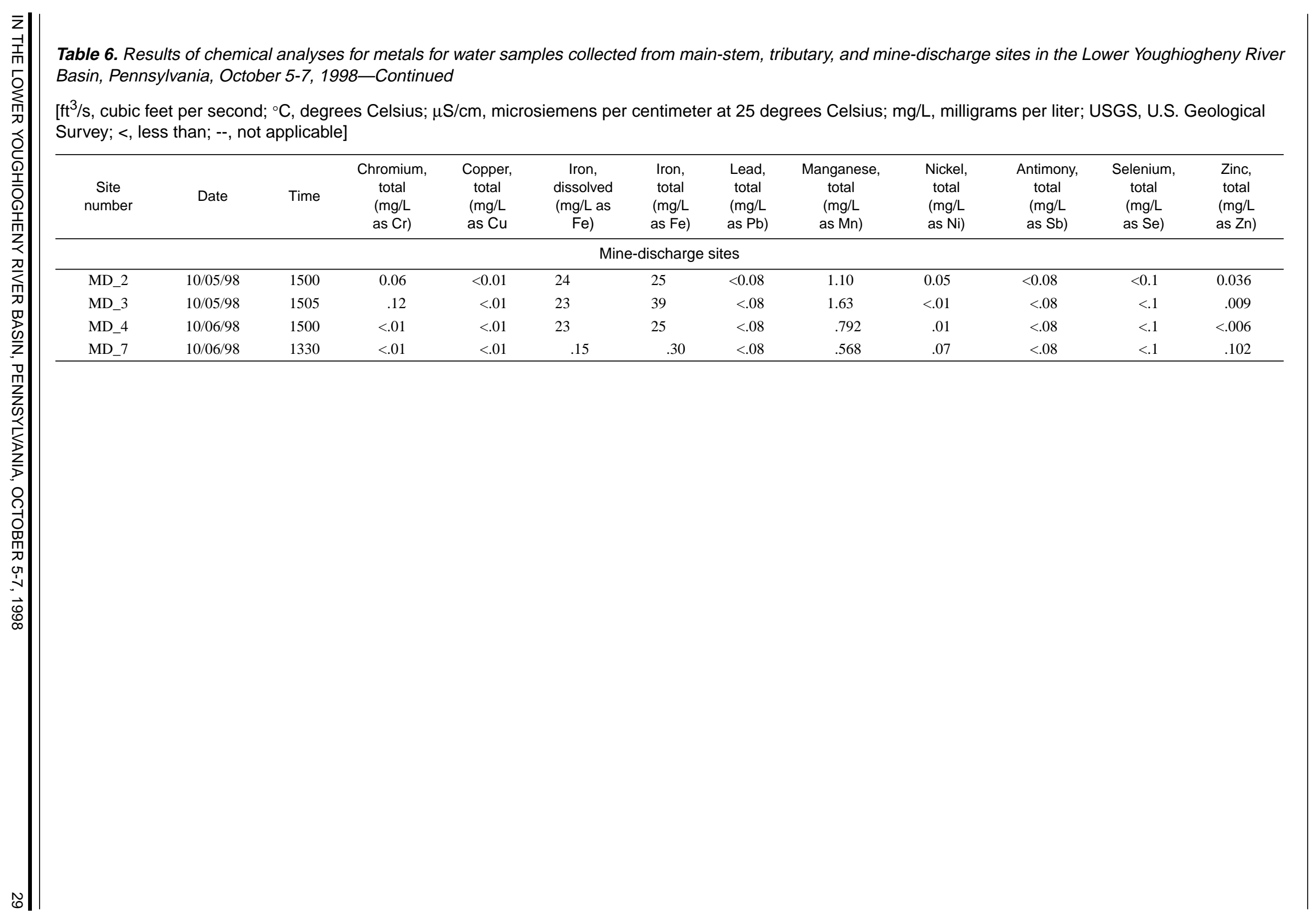




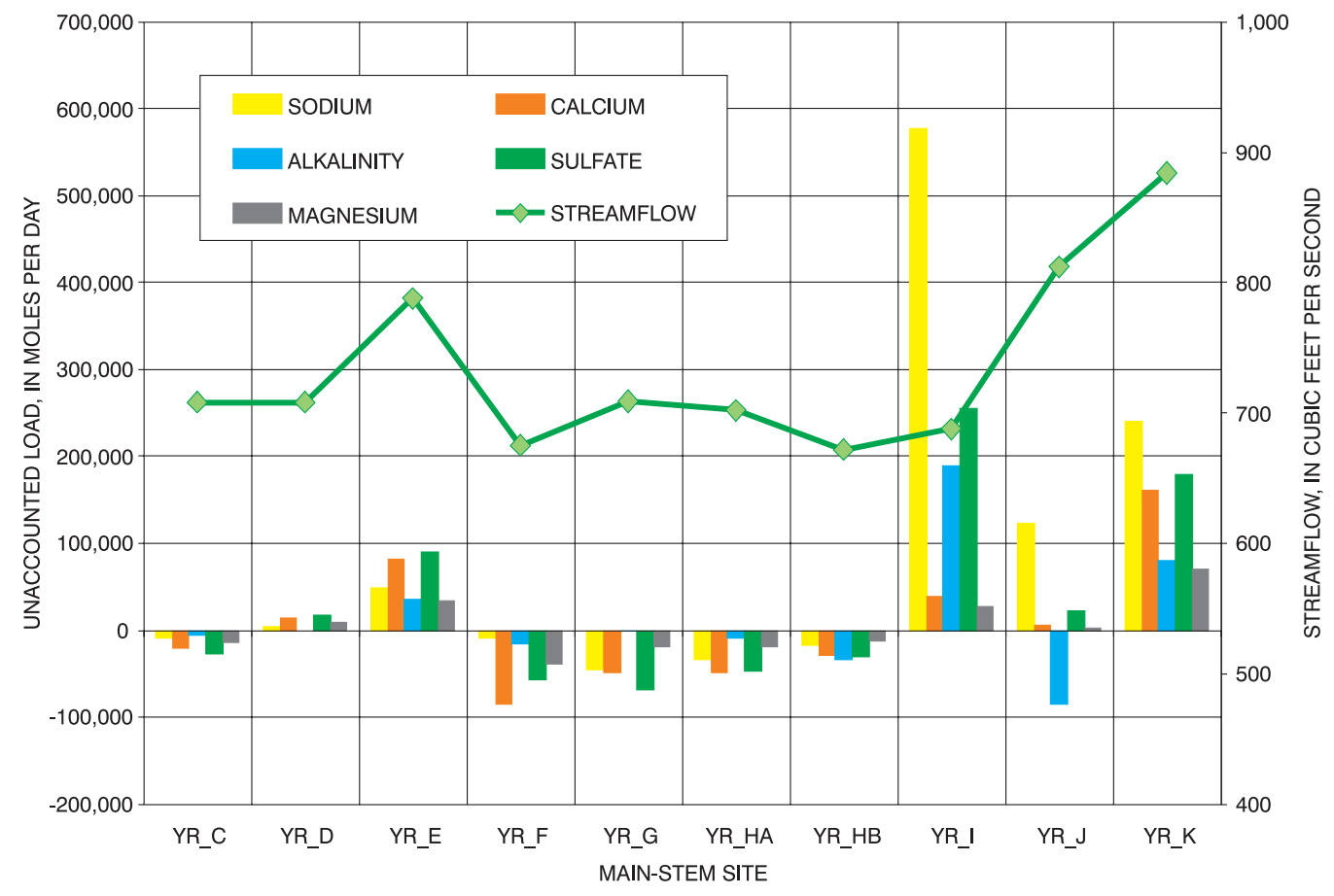

Figure 13. Total ion loads that were not accounted for in measurements of tributary inflows, Lower Youghiogheny River Basin, October 5-7, 1998

Between sites YR_I and YR_J, smaller unaccounted for gains of sodium and sulfate enter the Youghiogheny River and alkalinity is lost from the River. Sewickley Creek, with its large loads of ions, is a major tributary to the Youghiogheny River in this reach. As explained earlier, the oxidation of ferrous iron to ferric iron and the accompanying consumption of alkalinity in this reaction is believed to account for the loss of alkalinity.

Between sites YR_J and YR_K, the calculated loads of the major ions are larger than measured loads (fig. 13). Thus, ions are entering the Lower Youghiogheny River that are not accounted for in the tributary measurements. Seeps from underground mines are suspected as the source.

\section{COMPANION RESEARCH AT NATIONAL ENERGY TECHNOLOGY LABORATORY}

This synoptic survey has given a snapshot of the present (1998) water quality for the Lower Youghiogheny River and also has yielded insight into contaminant sources and their magnitude. The survey was successful in identifying reaches of the Youghiogheny
River where tributary inputs alone cannot account for the observed water-quality conditions. While this point-by-point survey can identify river reaches where other suspected inputs and losses are occurring, this traditional survey cannot pinpoint non-tributary inputs. The application of recently declassified remote sensing and mapping technologies will likely play a major role in addressing the contamination of the nation's streams and rivers. NETL currently is demonstrating the application of thermal infrared imaging in the Sewickley Creek watershed and the Lower Youghiogheny River Basin, as part of a new program to rapidly provide in-depth environmental characterization at the watershed and river-basin scale. A preliminary review of the thermal infrared imaging data clearly shows known mine-drainage discharges on the banks of the Youghiogheny River, including several apparent thermal plumes within the river channel, that strongly correspond with known mining activities and geologic settings (shallow overburden). Furthermore, this technology has detected well-known mine-drainagedischarge sites in the Sewickley Creek watershed and has targeted numerous other sites to investigate and/or characterize. Consequently, this approach appears 
capable of identifying mine-drainage flows coming out of the ground and river channel that were not identified with traditional surveys.

The historical data show mine-drainage sites affected the Youghiogheny River at the time when those samples were collected. Some of these discharges were not found during this survey. This result may indicate that fracturing in the streambed has provided a lower resistance path that allows the drainage to enter the river by subsurface routes. These subsurface discharges are difficult to locate and measure. However, the remote-sensing techniques may be useful for detecting the thermal signature of drainages entering through the fractured streambed. Once these contamination sources are identified, remediation strategies can be formulated and implemented.

\section{SUMMARY}

Historical water-quality data from 1967 to 1998 were compiled for the Lower Youghiogheny River Basin in Pennsylvania to identify major sources of mine-associated contaminants and areas of waterquality impairment. A total of 374 mine discharges were identified; 104 of these had both sulfate concentration data and flow data so that a sulfate load could be computed. Seven of the 10 largest contributors of sulfate load discharged directly to the Youghiogheny River rather than to a tributary. Three of the 10 largest contributors of sulfate load discharged to Sewickley Creek.

A synoptic survey of water-quality conditions in the Lower Youghiogheny River Basin was conducted during a low-flow period of October 5-7, 1998. During the survey, water quality in the Lower Youghiogheny River was generally good at most main-stem sites sampled. All main-stem sampling sites had $\mathrm{pH}$ values of 7.0 or higher. Concentrations of total iron at all mainstem sites ranged from 0.07 to $4.2 \mathrm{mg} / \mathrm{L}$. The largest concentrations of chemicals associated with drainage from coal-mining operations were noted in samples from tributaries, especially from Galley Run, Gillespie Run, and Sewickley Creek, and from the mine-discharge sites. At some locations, concentrations of dissolved iron, manganese, and aluminum exceeded water-quality standards. Impairment to aquatic organisms is likely at these locations. Sewickley Creek is the major contributor to all of the ion loads. This tributary stream alone accounts for 45 percent of the sulfate load entering the Lower Youghiogheny River.
Inputs from tributaries could not account for total loads of alkalinity and sulfate measured in the Youghiogheny River during the synoptic survey. Additional inputs that were not measured are entering the River. It is believed that these unmeasured inputs are, in part, seeps from underground mines that underlie the streambed. The synoptic survey described in this report was successful in identifying reaches where unmeasured inputs are entering the River, but pinpointing those inputs was not possible in this synoptic survey. Other techniques are needed to support the synoptic sampling. Remote-sensing techniques being tested by the NETL may be useful to precisely identify these inputs.

\section{REFERENCES CITED}

Eaton, A.D., Clesceri, L.S., and Greenburg, A.E., 1995, Standard methods for the examination of water and wastewater: Washington, American Public Health Association, variously paged.

Edmunds, W.E., and Koppe, E.F., 1968, Coal in Pennsylvania: Harrisburg, Pa., Pennsylvania Topographic and Geologic Survey Educational Series 7, $28 \mathrm{p}$.

Fales, H.A., and Kenny, Frederic, 1940, Inorganic quantitative analysis: New York, D. AppletonCentury Co., p. 434-435.

Gibbs \& Hill, Inc., 1971, Youghiogheny River Basin mine drainage pollution abatement project: Harrisburg, Pa., Pennsylvania Department of Environmental Resources.

Hem, J.D., 1985, Study and interpretation of the chemical characteristics of natural water: U.S. Geological Survey Water-Supply Paper 2254, $263 \mathrm{p}$.

Mackin Engineering, 1997, Lower Youghiogheny River conservation plan: Pittsburgh, Pa., 35 p. + appendixes.

National Atmospheric Deposition Program, 2000, National Atmospheric Deposition Program 1999 annual summary wet deposition: Champaign, Ill., Illinois State Water Survey, NADP Data Report 2000-02, 16 p.

Palmer, Tim, 1984, Youghiogheny Appalachian River: Pittsburgh, Pa., University of Pittsburgh Press, 337 p. 


\section{REFERENCES CITED-Continued}

Pennsylvania Coal Association, 1995, Pennsylvania Coal Data: Harrisburg, Pa., Keystone Bituminous Coal Association, 32 p.

Pennsylvania Department of Environmental Protection, 1998, Commonwealth of Pennsylvania 1998 Water Quality Assessment 305(b) Report: Harrisburg, Pa., Bureau of Watershed Conservation, $49 \mathrm{p}$.

Rantz, S.E., and others, 1982, Measurement and computation of streamflow-1. Measurement of stage and discharge: U.S. Geological Survey Water-Supply Paper 2175, v. 1, 284 p.

Sams, J.I., III, and Beer, K.M., 2000, Effects of coalmine drainage on stream water quality in the Allegheny and Monongahela River BasinsSulfate transport and trends: U.S. Geological Survey Water-Resources Investigations Report 99-4208, 17 p.

Searcy, J.K., 1959, Flow-duration curves, Manual of hydrology-Part 2, Low flow techniques: U.S. Geological Survey Water-Supply Paper 1542-A, $33 \mathrm{p}$.

Shelton, L.R., 1994, Field guide for collecting and processing stream-water samples for the National Water-Quality Assessment Program: U.S. Geological Survey Open-File Report 94-455, $42 \mathrm{p}$.
Siwicki, R.W., 2001, Water resources data, Pennsylvania, water year 2000, v. 3. Ohio and St. Lawrence River Basins: U.S. Geological Survey Water-Data Report PA-00-3, 204 p.

Smith, T.R., and Haines, T.A., 1995, Mortality, growth, swimming activity and gill morphology of brook trout (Salvelinus fontinalis) and Atlantic salmon (Salmo salar) exposed to low $\mathrm{pH}$ with and without aluminum: Environmental Pollution, v. 90, no. 1, p. 33-40.

Stumm, Werner, and Morgan, J.J., 1996, Aquatic chemistry chemical equilibria and rates in natural waters ( 3 d ed.): New York, John Wiley amd Sons, Inc., 1,022 p.

U.S. Environmental Protection Agency, 1983, Methods for chemical analysis of water and wastes: EPA-600/4-79-020, variously paged.

1995, Fisheries impacted by acid mine drainage: accessed November 10, 1998, at URL http://www.epa.gov/reg3giss/datalib/ metamd95.htm

U.S. Geological Survey, 1998, Land-cover information from LANDSAT thematic mapper (TM) data: accessed December 10, 1998, at URL http://wwwdcascr.wr.usgs.gov/pnsp/lci/

U.S. Office of Surface Mining, 1998, Abandoned Mine Land Program: accessed August 24, 1999, at URL http://www.osmre.gov/zintro2.htm 
Sams, J.I., III, Schroeder, K.T., Ackman, T.E., Crawford, J.K., and Otto, K.L.
Water-Quality Conditions During Low Flow in the Lower Youghiogheny River Basin, Pennsylvania, October 5-7, 1998 